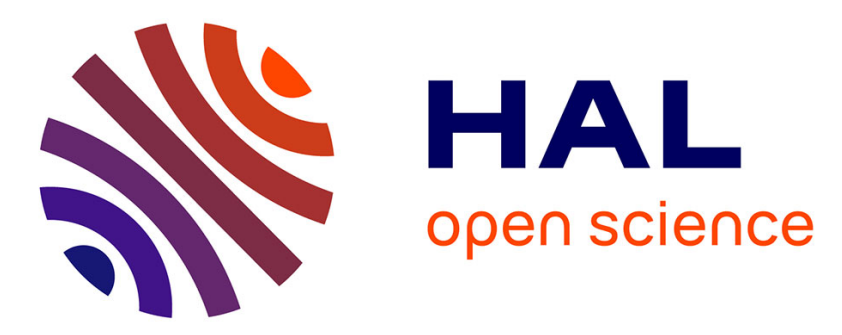

\title{
Mathematical modeling of CO 2 absorption with ionic liquids in a membrane contactor, study of absorption kinetics and influence of temperature
}

Sohaib Qazi, Lucía Gómez-coma, Jonathan Albo, Stéphanie Druon-bocquet, Angel Irabien, Mohammad Younas, José Sanchez-Marcano

\section{To cite this version:}

Sohaib Qazi, Lucía Gómez-coma, Jonathan Albo, Stéphanie Druon-bocquet, Angel Irabien, et al.. Mathematical modeling of CO 2 absorption with ionic liquids in a membrane contactor, study of absorption kinetics and influence of temperature. Journal of Chemical Technology and Biotechnology, 2020, 95 (7), pp.1844-1857. 10.1002/jctb.6265 . hal-02930318

\section{HAL Id: hal-02930318 https://hal.science/hal-02930318}

Submitted on 6 Nov 2020

HAL is a multi-disciplinary open access archive for the deposit and dissemination of scientific research documents, whether they are published or not. The documents may come from teaching and research institutions in France or abroad, or from public or private research centers.
L'archive ouverte pluridisciplinaire HAL, est destinée au dépôt et à la diffusion de documents scientifiques de niveau recherche, publiés ou non, émanant des établissements d'enseignement et de recherche français ou étrangers, des laboratoires publics ou privés. 


\title{
Mathematical Modelling of $\mathrm{CO}_{2}$ Absorption with Ionic Liquids in a Membrane Contactor, Study of Absorption Kinetics and Influence of Temperature
}

Sohaib Qazi ${ }^{1}$, Lucía Gómez-Coma ${ }^{2}$, Jonathan Albo ${ }^{2}$, Stéphanie Druon-Bocquet ${ }^{1}$, Angel Irabien ${ }^{2}$, Mohammad Younas ${ }^{3}$, José Sanchez-Marcano ${ }^{1}$

1: Institut Européen des Membranes, IEM - UMR 5635, CNRS, ENSCM, Université de Montpellier, Montpellier, France.

2: Chemical and Biomolecular Engineering Department, Universidad de Cantabria, Av. Los Castros, 39005 Santander, Spain.

3: Department of Chemical Engineering, University of Engineering and Technology, Peshawar, P.O. Box 814, University Campus, Peshawar 25120, Pakistan

\begin{abstract}
BACKGROUND: This work presents a comprehensive study of $\mathrm{CO}_{2}$ capture from $\mathrm{CO}_{2} / \mathrm{N}_{2}$ mixtures in a hollow fiber membrane contactor (HFMC). The absorbents considered were three different ionic liquids (ILs): 1-Ethyl-3-methylimidazolium acetate ([emim][OAc]), 1-ethyl-3-methylimidazolium ethylsulfate ([emim] $\left[\mathrm{EtSO}_{4}\right]$ ) and 1-ethyl-3-methylimidazolium methyl sulfate ([emim][$\left.\left[\mathrm{MeSO}_{4}\right]\right)$. A comprehensive 2-D mathematical model for the transport of $\mathrm{CO}_{2}$ was developed and solved for steady-state and pseudo steady-state modes. For pseudo steady-state mode, the 2-D model was linked with a dynamic model applied on a tank from which IL was recirculated into the shell side of the HFMC.

RESULTS: The model showed excellent agreement between the simulations and experimental data within the range of 2-5\% standard deviation. Initially, overall mass transfer coefficients of $7.6 \times 10^{-6}\left(\mathrm{~m} . \mathrm{s}^{-}\right.$

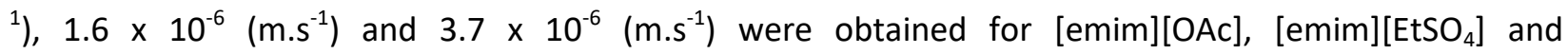
[emim] $\left[\mathrm{MeSO}_{4}\right]$, respectively. Solubility, diffusivity and absorption efficiency of $\mathrm{CO}_{2}$ in ILs showed strong dependence on the temperature. Furthermore, concentration drop in the wetted portion of the membrane, effect of porosity, tortuosity, gas and absorbent flow rates were systematically studied.
\end{abstract}

CONCLUSION: Findings of both experimental and modelling work suggests that in spite of the difference of extraction efficiency, these ILs are potential absorbents for $\mathrm{CO}_{2}$ in membrane contactors. Moreover, the modelling approach was found very effective to predict the absorption behavior of $\mathrm{CO}_{2}$ in ILs and to study the wetting phenomena and parametric effects.

Keywords: $\mathrm{CO}_{2}$ Absorption, $\mathrm{CO}_{2}$ solubility, Membrane Contactor, lonic Liquid, Modelling and Simulation. 


\section{Nomenclature}

A

C

D

E

$f$

H

$\Delta \hat{\mathrm{H}}$

j

K

Ḱ

$L$

ḿ

M

$n$

P

$Q$

$r$

$r_{1}$

$r_{2}$

$r_{3}$

$R$

Ŕ

$\mathfrak{R}_{g}$

$t$

$T$

$u$

$U$

$v$

V

$x$

Z
Area $\left(m^{2}\right)$

Concentration ( $\mathrm{mol} . \mathrm{m}^{-3}$ )

Diffusivity $\left(m^{2} . s^{-1}\right)$

Activation energy $\left(K J \cdot \mathrm{mol}^{-1}\right)$

Fugacity $(\mathrm{Pa})$

Henry's law constant $(\mathrm{Pa})$

Enthalpy (KJ. $\left.\mathrm{mol}^{-1}\right)$

Molar flux $\left(\mathrm{mol} . \mathrm{m}^{-2} . \mathrm{s}^{-1}\right)$

Equilibrium constant (-)

Mass transfer coefficient $\left(m . s^{-1}\right)$

Length of membrane $(m)$

Distribution factor of $\mathrm{CO}_{2}(-)$

Molar weight $\left(\mathrm{kg}^{\mathrm{mol}} \mathrm{mol}^{-1}\right)$

Number of fibers

Pressure $(\mathrm{Pa})$

Volumetric flowrate $\left(\mathrm{m}^{3} . \mathrm{s}^{-1}\right)$

Radial coordinate $(m)$

Inner radius of the tube $(\mathrm{m})$

Outer radius of the tube $(m)$

Radius of the free surface $(m)$

Module inner radius $(m)$

Reaction rate $\left(\mathrm{mol} . \mathrm{m}^{-3} . \mathrm{s}^{-1}\right)$

Perfect gas constant $\left(j \cdot \mathrm{mol}^{-1} \cdot \mathrm{K}^{-1}\right)$

Time $(s)$

Temperature $(K)$

Average velocity $\left(m \cdot s^{-1}\right)$

Velocity $\left(m . s^{-1}\right)$

Molar volume $\left(\mathrm{cm}^{3} \cdot \mathrm{mol}^{-1}\right)$

Volume $\left(\mathrm{m}^{3}\right)$

Mole fraction of $\mathrm{CO}_{2}$ in IL (-)

Axial coordinate $(m)$ 


\section{Subscripts}

$\begin{array}{ll}\mathrm{CO}_{2} & \text { Carbon dioxide } \\ \text { eq } & \text { Equilibrium } \\ \boldsymbol{g} & \text { Gas } \\ \boldsymbol{i} & \text { Component } i \\ \boldsymbol{I L} & \text { Ionic Liquid } \\ \text { in } & \text { Inlet } \\ \boldsymbol{l} & \text { Liquid } \\ \mathrm{N}_{2} & \text { Dinitrogen } \\ \text { out } & \text { Outlet } \\ \text { ov } & \text { Overall } \\ \mathrm{r} & \text { Radial } \\ \mathrm{Z} & \text { Axial }\end{array}$

\section{Greek Letters}

$\mu$

$\Theta$

$\rho$

$\bar{v}$

$\varepsilon$

$\tau$

$\mathcal{T}$

$\delta$

$\varphi_{\mathrm{v}}$

$\theta$

$\varnothing$
Viscosity $(c P)$

Contactor volumetric void fraction (-)

Density $\left(k g . \mathrm{m}^{-3}\right)$

Atomic diffusion volume (unity)

Membrane porosity (-)

Membrane tortuosity (-)

Ionic liquid residence time $(s)$

Membrane thickness $(m)$

$\mathrm{CO}_{2}$ amount in feed gas (\% vol)

Cylindrical coordinate (rad)

Fugacity coefficient (-) 


\section{Introduction}

Increased emissions of carbon dioxide $\left(\mathrm{CO}_{2}\right)$, a major greenhouse gas and climate change contributor, is a serious concern all over the world ${ }^{1-3}$. According to the International Panel of Climate Change (IPCC) for year 2100 it is estimated that the $\mathrm{CO}_{2}$ content in the atmosphere will reach 570 ppmv and the mean temperature will rise by $2^{\circ} \mathrm{C}^{3-5}$. Scientists and technologists are significantly focusing on carbon capture (CC), which is a promising route to reduce $\mathrm{CO}_{2}$ emissions. Pre-combustion and post-combustion (PC) technologies for $\mathrm{CC}$ have been extensively studied in recent years and presented as economical and efficient techniques to mitigate $\mathrm{CO}_{2}$ emissions. Among $\mathrm{CC}$ technologies, $\mathrm{PC}$ is a promising technique as it can be retrofitted to existing power plants ${ }^{6-9}$.

Numerous technologies are used for CC based on both physical and chemical process involving absorption, adsorption, membrane separation, conversion and cryogenic separation ${ }^{10,11}$. Membrane gas absorption (MGA) process integrates conventional gas-liquid absorption with membrane contactors as a base for mass transfer. Membrane contactors have a promising intensification potential with major advantages such as high specific surface area, independent gas-liquid flow rates, flexibility and modularity, while gas absorption leads to high selectivity and high driving force ${ }^{12-18}$. Various physical and chemical absorbents have been used for CC in membrane contactors. An absorbent is rated based on its selectivity for gas, good solubility, good reactivity, and high absorption, low energy consumption during regeneration, low volatility and high contact angle with the membrane ${ }^{19,20}$. Monoethanolamines ${ }^{21,22}$, diethanol amines ${ }^{22,23}$, methyldiethanolamine ${ }^{21-23}$, 2-amino-2-methyl-1-propanol ${ }^{22}$ and other absorbents

24,25 have been used for CC with membrane contactors in previous studies. Alternative absorption fluids namely ionic liquids (ILS) have been proposed to replace corrosive and volatile amine based solvents ${ }^{26-}$ 28.

ILs have been paid much attention in recent years and regarded as potential candidates for $\mathrm{CO}_{2}$ absorption. An IL is a salt, which consist exclusively of organic cations and inorganic or organic anions, with a melting point lower than $100{ }^{\circ} \mathrm{C}^{26}$. ILs are divided in two sub categories, room temperature ILs (RTILs) and task specific ILs (TSILs) ${ }^{8}$. RTILs are conventional ILs which behaves like typical physical absorbents for the solubility of gases. Solubility of gases in RTILs is mostly represented by Henry's Law constant. TSILs are able to absorb more $\mathrm{CO}_{2}$ compared to RTILs, due to both physical and chemical absorption. However, the regeneration of TSILs is very energy consuming and costly due to chemical bonding. Properties like high $\mathrm{CO}_{2}$ solubility, negligible volatility, high thermal stability, non-flammability, tunability and potential for replacing conventional absorbents are the major driving forces for research on ILs ${ }^{26,29-32}$. Many review studies on $\mathrm{CO}_{2}$ absorption with ILs have been reported in recent years. These studies have listed absorption capacities and parameters for a number of ILs with both physical and chemical absorption nature for $\mathrm{CO}_{2}{ }^{8,26,30,33,34}$. Other studies have focused on investigating pressuretemperature-composition data for $\mathrm{CO}_{2}$ absorption in various ILs followed by analysis of the data using an equation-of-state (EOS) model ${ }^{35-38}$.

Recently, many studies have been devoted to membrane absorption with membrane contactors using ILs as absorbent. IL [emim] $\left[\mathrm{EtSO}_{4}\right]$ which is reported to behave as a physical absorbent for $\mathrm{CO}_{2}$, has been used in many studies. This ionic liquid was used for both $\mathrm{SO}_{2}$ and $\mathrm{CO}_{2}$ capture in cross-flow membrane contactors ${ }^{39,40}$. This research group systematically performed the comparative analysis of $\mathrm{CO}_{2}$ capture in 
parallel-flow and cross-flow membrane contactors ${ }^{41}$. ILs 1-butyl-3-methyl-imidazolium tetrafluoroborate [bmim] $\left[\mathrm{BF}_{4}\right]$ and 1-(3- aminopropyl)-3-methyl-imidazolium tetrafluoroborate [apmim] $\left[\mathrm{BF}_{4}\right]$ have also been used with membrane contactors to study $\mathrm{CO}_{2}$ absorption and desorption. Chemical absorption with [apmim] $\left[\mathrm{BF}_{4}\right]$ showed very high absorption capacity but low regeneration even at high vacuum degrees 12. Influence of temperature on physical and chemical absorption of $\mathrm{CO}_{2}$ with [emim] $\left[\mathrm{EtSO}_{4}\right]$ and [emim][OAc] was studied by Gómez-Coma et $\mathrm{al}^{42}$. Jie et $\mathrm{al}^{43}$ and Chau et $\mathrm{al}^{44}$ used 1-butyl-3methylimidazolium dicyanamide [bmim] [DCA] in a pressure swing membrane absorption process for $\mathrm{CO}_{2}$ capture in membrane contactors.

Many studies on modelling of $\mathrm{CO}_{2}$ absorption in membrane contactors have been published previously. However, up to the authors knowledge there is no study available on two dimensional (2-D) dynamic modelling of both physical and chemical absorption of $\mathrm{CO}_{2}$ in ILs, with an effective study of the temperature influence. 2-D model is an approach allowing calculating both axial and radial mass transfers. Then the model is applicable to real absorption situations. It also allows to evaluate the role of absorbent, membrane and hydrodynamics separately as it has been suggested in the review of Zhao et $\mathrm{al}^{9}$. In the present study, a comprehensive 2-D mass transfer model was developed for $\mathrm{CO}_{2}$ absorption (chemical \& physical) in membrane contactors with three different ILs (same cation and different anions) namely, 1-Ethyl-3-methylimidazolium acetate ([emim][OAc]), 1-ethyl-3-methylimidazolium ethylsulfate ([emim][EtSO 4$]$ ) and 1-ethyl-3-methylimidazolium methyl sulfate ([emim][MeSO 4$]$ ). Both, [emim][OAc] and $\left[\right.$ emim] $\left[\mathrm{EtSO}_{4}\right]$ are efficient absorbents for $\mathrm{CO}_{2}$ having low values of Henry constant high values of viscosities and considerable values of surface tension to avoid wetting of membrane pores. [emim] $\left[\mathrm{MeSO}_{4}\right]$ is a potential absorbent for $\mathrm{CO}_{2}$, based on the solubility data and Henry's law constants reported by Yim et al. ${ }^{36}$, Mejía et al. ${ }^{34}$ and Finotello et al. $^{45}$ in their studies. This IL has not been considered until now for $\mathrm{CO}_{2}$ absorption on membrane contactors. Moreover, [emim] $\left[\mathrm{MeSO}_{4}\right]$ is a viscous IL with a very high value of surface tension among other ILs. These properties make it a potential candidate for using it with hydrophobic membranes to avoid membrane wetting. Structures of the considered ILs are presented in Figure 1.

\section{Figure 1}

Counter current gas-IL arrangements were adopted for the model. Detailed concentration profiles (both axial and radial) for all three IL were developed. Evolution of overall mas transfer coefficient $\left(\mathrm{K}_{\mathrm{ov}}\right)$ with recirculation time of absorbents was studied. Effects of temperature on diffusivity (ILs and gas phase) and Henry constant of the three ILs were investigated. These parameters were further linked with the model in order to investigate temperature effects on the absorption behavior of $\mathrm{CO}_{2}$ with the ILs.

\section{Model development}

A comprehensive 2-D model is presented here for $\mathrm{CO}_{2}$ mass transport in a hollow fiber membrane contactor for both steady-state and pseudo steady-state modes. The process is explained in Figure 2 . The dotted lines show steady-state mode in which both gas and IL are passed from the membrane contactor in a non-closed loop. In the pseudo steady-state mode IL is recirculated from a reservoir which is represented by solid lines while gas flows in a non-closed loop. Fresh $\mathrm{CO}_{2} / \mathrm{N}_{2}$ gaseous mixture is 
introduced into the inner side of hollow fibers. While IL flows in the shell side either in a closed loop or non-closed loop. For pseudo steady-state mode, a dynamic model is linked with the mass transport model for the recirculated IL in the tank.

Figure 2

A polypropylene membrane contactor module with the same properties than Liquicel ${ }^{\mathrm{TM}}$ membrane contactors (USA) with macro-mesoporous, thin walled, opaque, polypropylene hollow-fibers was considered for the separation of $\mathrm{CO}_{2}$ from $\mathrm{CO}_{2} / \mathrm{N}_{2}$ mixture using ILs. Characteristics of the module and operating conditions are presented in Table 1. Properties of the three ILs studied here, are presented in Table 2. As described in the introduction, [emim] [OAc] and [emim] [EtSO $\left.\mathrm{E}_{4}\right]$ are efficient absorbents for $\mathrm{CO}_{2}$ having high value of viscosity and considerable value of surface tension to avoid wetting membrane pores. [emim] $\left[\mathrm{MeSO}_{4}\right]$ is the less viscous IL but presents the highest value of surface tension among ILs studied. These properties make it also a potential candidate for using it in membrane contactors. In order to reach reasonable computing times, we considered for the model establishment a single hollow fiber with arbitrary shell predicted by Happel's model ${ }^{46}$. A portion of the fiber along with the arbitrary shell (Figure 3) was modeled. Continuity equations were solved for the three domains of the flow cell namely, tube, membrane and shell.

\section{Table 1}

Table 2

Figure 3

The mass transport model of the flow cell (Figure 3 ) is based on the following assumptions:
a) Countercurrent mode for gas and IL flow in membrane contactor
b) Fully developed velocity profile in the shell and tube
c) Steady-state and isothermal conditions inside HFMC module (unless mentioned)
d) Laminar flow conditions
e) Application of Henry's law on gas-liquid interface
f) Non-selective behavior of the membrane
g) Perfectly stirred absorbent tank

\subsection{Mass transfer equations}

A schematic diagram of the countercurrent flow of gas and IL is shown in Figure 3. Mass balances were carried out for each of the three domains shown in Figure 3. The continuity equation for each section is expressed as:

$\frac{\partial C_{i}}{\partial t}=-\nabla \cdot C_{i} U-\nabla \cdot j_{i}+\dot{\mathrm{R}}_{i}$

Where the concentration of the species is $C_{i}\left(m o l . m^{-3}\right), U\left(\mathrm{~ms}^{-1}\right)$ is the velocity, $j_{i}\left(m o l . m^{-2} \cdot s^{-1}\right)$ is the molar flux, $\mathrm{R}_{\mathrm{i}}\left(\mathrm{mol} \cdot \mathrm{m}^{-3} \cdot \mathrm{s}^{-1}\right)$ is the reaction rate and $\mathrm{t}(\mathrm{s})$ is the time. The steady-state form of the equation is presented below: 
$0=-\nabla \cdot C_{i} U-\nabla \cdot j_{i}+\dot{\mathrm{R}}_{i}$

Terms on the right-hand side of the equation represents convection, diffusion and reaction. Fick's law of diffusion is applicable for the diffusion in membrane contactor ${ }^{47}$.

\subsubsection{Lumen side of the membrane contactor}

Transport of gas in the inner (tube) side is due to axial radial diffusion and axial convection. Equation 1 can be rewritten for the tube side as below.

$$
\frac{\partial C_{\mathrm{CO}_{2}-\text { tube }}}{\partial t}+D_{\mathrm{CO}_{2}-\text { tube }}\left[\frac{\partial^{2} C_{\mathrm{CO}_{2}-\text { tube }}}{\partial r^{2}}+\frac{1}{r} \frac{\partial C_{\mathrm{CO}_{2}-\text { tube }}}{\partial r}+\frac{\partial^{2} C_{\mathrm{CO}_{2}-\text { tube }}}{\partial z^{2}}\right]=U_{z-t u b e} \frac{\partial C_{\mathrm{CO}_{2}-\text { tube }}}{\partial z}
$$

Equation can be expressed in steady-state as below.

$D_{\mathrm{CO}_{2}-\text { tube }}\left[\frac{\partial^{2} C_{\mathrm{CO}_{2}-\text { tube }}}{\partial r^{2}}+\frac{1}{r} \frac{\partial C_{\mathrm{CO}_{2}-\text { tube }}}{\partial r}+\frac{\partial^{2} C_{\mathrm{CO}_{2}-\text { tube }}}{\partial z^{2}}\right]=U_{z-t u b e} \frac{\partial C_{\mathrm{CO}_{2}-\text { tube }}}{\partial z}$

$\mathrm{CO}_{2}$ gas phase diffusivity in equation 3 and 4 can be estimated by the following expression ${ }^{48}$ :

$D_{\mathrm{CO}_{2}-\text { tube }}=\frac{0.01013 . T^{1.75}\left(\frac{1}{M_{C O_{2}}}+\frac{1}{M_{N_{2}}}\right)^{0,5}}{P *\left[\left(\sum \overline{\mathrm{v}}_{\mathrm{CO}_{2}}\right)^{\frac{1}{3}}+\left(\sum \overline{\mathrm{v}}_{\mathrm{N}_{2}}\right)^{\frac{1}{3}}\right]^{2}}$

In the above equation $\bar{u}$ is the atomic diffusion volume. The validation of the correlation has been verified by many authors in previous studies ${ }^{49-51}$.

As the velocity profile inside the tube is laminar, the velocity distribution can be expressed by equation (6).

$U_{z-t u b e}=2 u_{\text {tube }}\left[1-\left(\frac{r}{r_{1}}\right)^{2}\right]$

Where $u_{\text {tube }}\left(m \cdot s^{-1}\right)$ in equation 6 represents average velocity of the gas in the tube.

Boundary conditions are listed in table 3.

\subsubsection{Porous membrane}

Axial and radial diffusion are considered for mass transfer in membrane. Then, equation 1 can be rewritten for the membrane as below:

$\frac{\partial C_{\mathrm{CO}_{2} \text {-tube }}}{\partial t}+D_{\mathrm{CO}_{2}-\text { membrane }}\left[\frac{\partial^{2} C_{\mathrm{CO}_{2}-\text { membrane }}}{\partial r^{2}}+\frac{1}{r} \frac{\partial C_{\mathrm{CO}_{2}-\text { membrane }}}{\partial r}+\frac{\partial^{2} C_{\mathrm{CO}_{2}-\text { membrane }}}{\partial z^{2}}\right]=0$

For steady-state mode the equation can be expressed as below.

$D_{\mathrm{CO}_{2} \text {-membrane }}\left[\frac{\partial^{2} C_{\mathrm{CO}_{2}-\text { membrane }}}{\partial r^{2}}+\frac{1}{r} \frac{\partial C_{\mathrm{CO}_{2}-\text { membrane }}}{\partial r}+\frac{\partial^{2} C_{\mathrm{CO}_{2}-\text { membrane }}}{\partial z^{2}}\right]=0$

Effective diffusivity inside the porous membrane is expressed as: 
$D_{\mathrm{CO}_{2}-\text { membrane }}=D_{\mathrm{CO}_{2}-\text { tube }} \frac{\varepsilon}{\tau}$

Where $\varepsilon$ and $\tau$ represents porosity and tortuosity of the porous membrane.

Boundary conditions are listed in table 3.

\subsubsection{Shell side of the membrane contactor}

ILs flow counter currently through the shell side of the contactor. IL [emim][OAc] is found to behave as both physical and chemical absorbent for $\mathrm{CO}_{2}{ }^{35,37}$ while both [emim] $\left[\mathrm{EtSO}_{4}\right.$ ] and [emim] $\left[\mathrm{MeSO}_{4}\right.$ ] behave as physical absorbent for $\mathrm{CO}_{2}{ }^{36,52,53}$.

$\mathrm{CO}_{2}$ solubility in ILs is mostly represented by Henry's law constant. Moreover, generally the models consider Henry's law for the gas liquid interface. Indeed, the calculations of this constant are of high importance for the modeling of $\mathrm{CO}_{2}$ absorption on ILs. The magnitude of the Henry's constant indicates whether the absorption is chemical or physical. A small value of Henry's constant (usually less than 3 $\mathrm{MPa}$ ) denotes chemical absorption of $\mathrm{CO}_{2}$ in ILs ${ }^{35,54}$ and high gas solubility ${ }^{28,55}$. In this work the experimental PTx data (vapour-liquid equilibria: VLE) were obtained from the literature for the three ILs $[\mathrm{emim}][\mathrm{OAc}]^{36},[\mathrm{emim}]\left[\mathrm{EtSO}_{4}\right]^{52,53}$, [emim] $\left[\mathrm{MeSO}_{4}\right]^{36}$. Henry's constants were calculated from these experimental PTx data using the following equation ${ }^{35,56-58}$ :

$H(T, P)=\lim _{x \rightarrow 0} \frac{f\left(T, P, x_{\mathrm{CO}_{2}}\right)}{x_{\mathrm{CO}_{2}}}=\lim _{x \rightarrow 0} \frac{\emptyset\left(T_{e q}, P_{e q}\right) P_{e q}}{x_{\mathrm{CO}_{2}}}$

Where $\mathrm{H}(\mathrm{Pa})$ is the Henry's constant, $f$ is the fugacity of $\mathrm{CO}_{2}, x_{\mathrm{CO}_{2}}$ is the mole fraction of $\mathrm{CO}_{2}$ dissolved in IL, $\emptyset$ is the fugacity coefficient, $T_{e q}$ is the equilibrium temperature and $P_{e q}$ is the equilibrium pressure. As the solubility varies with temperature, equation 10 allowed calculating Henry's constant at various temperatures. As described in the introduction, the three ILs studied are efficient absorbents for $\mathrm{CO}_{2}$ having low values of Henry constant. Values of this constant, for the three ILs, at $298 \mathrm{~K}$ are listed in table 4. The constant found from equation 10 was used in the following equation to calculate dimensionless Henry's constant ${ }^{58}$ :

$\mathrm{m}=\frac{\rho_{I L} \mathcal{R}_{g} T}{M_{I L} H}$

Where $\rho_{I L}\left(\mathrm{~kg}^{\mathrm{m}} \mathrm{m}^{-3}\right)$ is the density of IL, $\mathcal{R}_{\mathrm{g}}\left(\mathrm{m}^{3} \cdot \mathrm{Pa} \cdot \mathrm{K}^{-1} \cdot \mathrm{mol}^{-1}\right)$ is the gas constant, $M_{I L}\left(\mathrm{~kg}^{\mathrm{mol}} \mathrm{mol}^{-1}\right)$ is the molar weight of IL, T $(\mathrm{K})$ is the temperature and $\mathrm{H}(\mathrm{Pa})$ Henry's law constant for $\mathrm{CO}_{2}$ in the three ILs. For the three ILs, [emim][OAc], [emim] $\left[\mathrm{EtSO}_{4}\right]$, [emim] $\left[\mathrm{MeSO}_{4}\right]$, densities had strong dependency on temperature which in turn affected the Henry's constant and solubility of $\mathrm{CO}_{2}$. Temperature dependency of the density for the three ILs [emim][OAc], [emim] [ $\left.\mathrm{EtSO}_{4}\right]$, [emim][ $\left.\mathrm{MeSO}_{4}\right]$ are shown in equations 12, 13 , and 14 , respectively ${ }^{52,59-62}$. Equations below correspond to density in $\mathrm{kg} \cdot \mathrm{m}^{-3}$ and temperature in $\mathrm{K}$ :

$$
\begin{aligned}
& \rho(T)=1280.8+0.608 T \\
& \rho(T)=1451.5928-0.757562 T+0.00013391 T^{2} \\
& \ln \rho(T)=7.33100-6.17220 \times 10^{-4} T+1.3862 \times 10^{-4} T^{2}
\end{aligned}
$$


The reaction term of equation 6 is neglected for all three ILs. Experimental solubility data from the literature at VLE is used to measure the Henry's constant and partition coefficient for $\mathrm{CO}_{2}$ solubility in ILs. The experimental solubility data covers both physical and chemical absorption. The partition coefficient (equation 2) measured from the experimental VLE solubility data of $\mathrm{CO}_{2}$ was used to define the concentration distribution across the gas-liquid interface which resides on/or between the two boundaries of porous membrane depending upon the conditions whether the membrane is wetted or non-wetted (figure 3). Values of Henry's constant are presented in table 4. Gómez-Coma et al. ${ }^{63}$ transformed the value of overall mass transfer coefficient for [emim][OAc] to a reaction constant. The transformed constant agrees with the first order gas liquid chemical reaction:

$K_{r}=K_{\text {ov }} \frac{\text { Fiber Area }}{\text { Shell Volume }}$

Furthermore, the activation energy was calculated using Arrhenius equation:

$K_{r}=B e^{\frac{-E a}{R T}}$

Where $\mathrm{B}$ is the pre-exponential factor, $E_{a}$ is the activation energy $\left(J \cdot \mathrm{mol}^{-1}\right), \mathrm{R}$ is the gas constant $8.31 \mathrm{~J} . \mathrm{K}^{-1} \mathrm{~mol}^{-1}$, and $\mathrm{T}$ is the temperature $(K)$. These values are presented in table 4 along with the equilibrium constant and enthalpy of complex formation ${ }^{35,38}$.

Transport of $\mathrm{CO}_{2}$ in the shell side is due to axial radial diffusion and axial convection. Based on the above assumptions, equation 1 can be rewritten for the shell side as below:

$\frac{\partial C_{\mathrm{CO}_{2} \text {-tube }}}{\partial t}+D_{\mathrm{CO}_{2}-\text { shell }}\left[\frac{\partial^{2} C_{\mathrm{CO}_{2}-\text { shell }}}{\partial r^{2}}+\frac{1}{r} \frac{\partial C_{\mathrm{CO}_{2}-\text { shell }}}{\partial r}+\frac{\partial^{2} C_{\mathrm{CO}_{2}-\text { shell }}}{\partial z^{2}}\right]=U_{z-\text { shell }} \frac{\partial C_{\mathrm{CO}_{2} \text {-shell }}}{\partial z}$

For steady-state mode equation 17 can be rewritten as follows:

$D_{\mathrm{CO}_{2}-\text { shell }}\left[\frac{\partial^{2} C_{\mathrm{CO}_{2}-\text { shell }}}{\partial r^{2}}+\frac{1}{r} \frac{\partial C_{\mathrm{CO}_{2}-\text { shell }}}{\partial r}+\frac{\partial^{2} C_{\mathrm{CO}_{2}-\text { shell }}}{\partial z^{2}}\right]=U_{z-\text { shell }} \frac{\partial C_{\mathrm{CO}_{2}-\text { shell }}}{\partial z}$

$D_{\mathrm{CO}_{2}-\text { shell }}$ can be expressed as ${ }^{64}$ :

$D_{\mathrm{CO}_{2}-\text { shell }}=2.66 \times 10^{-3} \frac{1}{\mu_{I L}^{0.66} v_{C O_{2}}^{1.04}}$

Where $\mu_{I L}(m P a . s)$ and $v_{\mathrm{CO}_{2}}\left(\mathrm{~cm}^{3} \cdot \mathrm{mol}^{-1}\right)$ are viscosity of IL and molar volume of $\mathrm{CO}_{2}$. Temperature dependency of the viscosity for the three ILs [emim][OAc], [emim] $\left[\mathrm{EtSO}_{4}\right]$, [emim] $\left[\mathrm{MeSO}_{4}\right]$ are presented in equations below, respectively ${ }^{52,59-62}$. Equations below correspond to viscosity in $(m P a . s)$ and temperature in $\mathrm{K}$ :

$$
\begin{aligned}
& \ln \mu(T)=-1.657+\left(\frac{673.7}{T-196.1}\right) \\
& \ln \mu(T)=-1.6558+\left(\frac{792.98}{T-171.15}\right) \\
& \ln \mu(T)=\ln \rho M-18.25+\left(\frac{1266.1}{T}\right)
\end{aligned}
$$


Equation 19 developed by Morgan et al. ${ }^{64}$ is based on the $\mathrm{CO}_{2}$ diffusivities in imidazolium cation based ILs with different anions. Many authors have confirmed this correlation by comparing experimental diffusivities with the diffusivities measured by this correlation ${ }^{56,65}$. Calculated values of $\mathrm{CO}_{2}$ diffusivity, for the three ILs, at $293 \mathrm{~K}$ are listed in table 4.

Velocity profile inside the shell is expressed by Happel's free surface model ${ }^{46}$.

$U_{z-\text { shell }}=2 u_{\text {shell }}\left[1-\left(\frac{r_{2}}{r_{3}}\right)^{2}\right] \frac{\left(r / r_{3}\right)^{2}-\left(r_{2} / r_{3}\right)^{2}+2 \ln \left(r_{2} / r\right)}{3+\left(r_{2} / r_{3}\right)^{4}-4\left(r_{2} / r_{3}\right)^{2}+4 \ln \left(r_{2} / r_{3}\right)}$

Where $u_{\text {shell }}, r_{2}$ and $r_{3}$ are average velocity of absorbent in the shell, outer radius of fiber and radius of free surface. The relationship between $r_{2}$ and $r_{3}$ is expressed as:

$r_{3}=\left(\frac{1}{1-\Theta}\right)^{1 / 2} r_{2}$

Where $\Theta$ is the volume fraction of the void space, which can be calculated from the following equation:

$$
1-\Theta=\frac{n r_{2}^{2}}{R^{2}}
$$

Where $n$ is the number of fibers and $R$ is the module inner radius.

Boundary conditions are listed in Table 3.

\section{Table 3}

\section{Table 4}

\subsubsection{Dynamic model: Pseudo steady-state}

As it has been explained in the preceding sections, in the pseudo steady-state mode IL passing through the shell side of the membrane contactor is recirculated from the tank as shown in Figure 2. $\mathrm{CO}_{2}$ concentration gradually increases in the IL phase with the number of circulation-paths in the membrane contactor setup. The $\mathrm{CO}_{2}$ concentration evolution with time was calculated by applying a transient differential equation around the tank:

$Q_{I L}\left(C_{C O_{2}-Z=0}(t)-C_{C O_{2}-\operatorname{tank}}(t)\right)=V_{I L} \frac{d C_{C O_{2}-\operatorname{tank}(t)}}{d t}$

Where $C_{\mathrm{CO}_{2}-\text { tank }}(t)$ is $\mathrm{CO}_{2}$ concentration $\left(\mathrm{mol} . \mathrm{m}^{-3}\right)$ in tank at time $t, C_{\mathrm{CO}_{2}-\mathrm{Z}=0}(t)$ is shell side concentration (mol. $\mathrm{m}^{-3}$ ) of $\mathrm{CO}_{2}$ at $\mathrm{z}=0$ which is the exit of the contactor to the absorbent tank, $V_{I L}\left(\mathrm{~m}^{3}\right)$ and $Q_{I L}\left(\mathrm{~m}^{3} \cdot \mathrm{s}^{-1}\right)$ are the total volume and the volumetric flow rate of ionic liquid. Solving equation (26) for the $\mathrm{CO}_{2}$ concentration in the tank at time $t+\Delta t$ gives the following expression:

$C_{\mathrm{CO}_{2}-\operatorname{tank}}(t+\Delta t)=\frac{\Delta t}{\mathcal{T}_{I L}} C_{\mathrm{CO}_{2}-Z=0}(t)+C_{\mathrm{CO}_{2}-\operatorname{tank}}(t)\left[1+\frac{\Delta t}{\mathcal{T}_{I L}}\right]$

where $\mathcal{T}_{I L}=\frac{V_{I L}}{Q_{I L}}$ is the residence time of IL in the tank. 
$C_{\mathrm{CO}_{2}-\mathrm{Z}=0}(t)$ was found using the following boundary integration equation:

$C_{\mathrm{CO}_{2}-\mathrm{Z}=0}(t)=\frac{\iint_{r=r_{2}}^{r=r_{3}} C_{\mathrm{CO}_{2}-\text { shell }}(r) r d r d \theta}{\iint_{r=r_{2}}^{r=r_{3}} r d r d \theta}$

\subsubsection{Model simulation and numerical approach}

The set of equations for tube, membrane and shell side presented in the preceding sections were coupled and solved using COMSOL Multiphysics ${ }^{\circledR}$ (version 5.3a, 2018) and MATLAB R2017a using LiveLink $^{\mathrm{TM}}$ for MATLAB ${ }^{\circledR}$. The model equations were solved using PARDISO solver, which is a high performance, robust and memory efficient solver for solving large sparse symmetric and non-symmetric linear system of equations. The finite element method was used to solve partial differential equations. Mapped meshing was applied with 4 different distributions for different boundaries. For pseudo steadystate study, a time dependent solver was applied while keeping the same mapping and solver configurations. The time dependent solver was set for BDF (backward differentiation formula) time stepping, with strict steps for the solver. BDF is an implicit solver that uses backward differentiation formulas with variation from 1-5 in order of accuracy. BDF methods are known for their higher stability and provides variable orders. A higher order is used when needed and a lower order is automatically employed when it is required for stability. The process was fully coupled.

As for pseudo steady-state mode the concentration is constantly evolving with time. The evolution of $\mathrm{CO}_{2}$ concentration with recirculation of IL was measured by equation (27). Dynamic equation was coupled with the mass transfer equations. $C_{\mathrm{CO}_{2}-\mathrm{Z}=0}(t)$ term for the dynamic model was defined from the boundary integral equation (28) after solving the mass transfer equations in COMSOL. The code for the dynamic model predicts the change in concentration of $\mathrm{CO}_{2}$ in the $\mathrm{IL}$ tank for the time $t+\Delta t$. Equation 27 defines input concentration of the absorbent side which for the steady-state is always zero (fresh solvent).

\section{Results and discussion}

\subsection{Pseudo steady-state mode}

\subsubsection{Model validation: Comparison of simulation data with experimental results}

Modelling results were compared with experimental data available from Gómez-Coma et al. ${ }^{42}$ who used a polypropylene HFMC supplied by Liquice ${ }^{\mathrm{TM}}$-Membrane Contactors (USA) (Table 1) in their study. Nonwetting conditions were assumed due to the fact of applying a slight transmembrane pressure difference. Considered ILs are highly viscous and have high values of surface tension (Table 2), making very feasible conditions for non-wetting of membrane.

For the model validation, we compared the calculated dimensionless concentration of $\mathrm{CO}_{2}$ at the outlet of the tube (gas phase) against time with the experimental results for the three ILs ${ }^{42}$. ILs flow rate was kept at $50 \mathrm{ml} \cdot \mathrm{min}^{-1}$ while gas flow rate was kept at $70 \mathrm{ml} \cdot \mathrm{min}^{-1}$. The $\mathrm{CO}_{2}$ composition in the gas was $15 \%$ by volume. Figure 4 (a) shows the results obtained for physical and chemical absorption of $\mathrm{CO}_{2}$ with [emim][OAc] at two different temperatures. A gradual increase in outlet concentration of $\mathrm{CO}_{2}$ can be 
observed. It is evident from the results that the proposed model reproduces the experimental data reasonably. Figure 4 (b) presents the similar results for physical absorption of $\mathrm{CO}_{2}$ with [emim] $\left[\mathrm{EtSO}_{4}\right]$ and $[\mathrm{emim}]\left[\mathrm{MeSO}_{4}\right]$. It can be seen that the simulation results for [emim] $\left[\mathrm{EtSO}_{4}\right]$ are in good agreement with the corresponding experimental results. In this work, another IL [emim] $\left[\mathrm{MeSO}_{4}\right.$ ] (having no experimental data available in the literature for $\mathrm{CO}_{2}$ absorption with [emim] $\left[\mathrm{MeSO}_{4}\right]$ using membrane contactors) with different absorption kinetics, was also studied. The ILs [emim] $\left[\mathrm{MeSO}_{4}\right]$ and [emim] $\left[\mathrm{EtSO}_{4}\right]$ have the same [emim] cation and are reported to behave as physical absorbents for $\mathrm{CO}_{2}$ with some slight differences in the physical constants. It has been reported that the solubility of $\mathrm{CO}_{2}$ in the IL increases with the alkyl chain of the imidazolium cation. However, the effect of alkyl chain cations on the solubility of $\mathrm{CO}_{2}$ is very less compared to anions. $\mathrm{CO}_{2}$ molecules show greater affinity for the anions $^{30}$. Performance of the membrane contactor gas absorption system is not only dependent on the solubility. Viscosity (affects diffusivity and flow of absorbent) and surface tension (affects wetting of the porous membrane) have also a strong influence on the performance. Indeed, as an initial approach the experimental values of $\mathrm{CO}_{2}$ absorption with [emim] $\left[\mathrm{EtSO}_{4}\right.$ ] in a $\mathrm{HFMC}$ were used for the validation of the model when [emim] $\left[\mathrm{MeSO}_{4}\right]$ is considered as extracting fluid. IL [emim] $\left[\mathrm{MeSO}_{4}\right]$ showed the same evolution of outlet concentration with recirculation time.

The results showed that even if the shape of the evolution is correct with time, the model always underestimates the experimental results. However, if experimental errors are considered, the standard deviations between the calculated and experimental results are ranged only between $2 \%$ to $5 \%$.

\section{Figure 4}

\subsubsection{Axial concentration distribution}

The simulations of the 2-D axial concentration profile of $\mathrm{CO}_{2}$ in the tube are presented in Figure 5. The gas mixture was introduced in the tube side at $z=0$. Moving toward $z=L$ causes a gradual decrease in $\mathrm{CO}_{2}$ concentration as it is absorbed progressively. Mass transfer in radial direction is mostly affected by diffusion while convection is the dominant mechanism for axial mass transfer due to gas flow. Figure 5(a) shows concentration profile of $\mathrm{CO}_{2}$ with IL [emim] [OAc] at $\mathrm{t}=1 \mathrm{~min}$ and $\mathrm{t}=100 \mathrm{~min}$. This figure shows that very small contactor length is required to capture the whole amount of $\mathrm{CO}_{2}$, initially, which verifies the presence of a very strong driving force. It is evident that even after 100 minutes of recirculation [emim] [OAc] is still able to capture $\mathrm{CO}_{2}$. Concentration distribution of $\mathrm{CO}_{2}$ with IL [emim] $\left[\mathrm{EtSO}_{4}\right.$ ] is presented in Figure $5(\mathrm{~b})$. This figure shows that initially [emim] $\left[\mathrm{EtSO}_{4}\right]$ is able to capture the whole amount of $\mathrm{CO}_{2}$ but unlike [emim][OAc], even after 40 minutes the IL is almost unable to capture more $\mathrm{CO}_{2}$. Moreover, compared to [emim] [OAc] a larger contactor length is required. [emim][OAc] was more efficient because of the lower Henry's constant and higher $\mathrm{CO}_{2}$ absorption ratio at VLE. IL [emim] $\left[\mathrm{MeSO}_{4}\right]$ as a physical absorbent is more efficient compared to [emim] $\left[\mathrm{EtSO}_{4}\right]$ as it captures $\mathrm{CO}_{2}$ with a smaller contactor length and is able to absorb more $\mathrm{CO}_{2}$ after 40 minutes. The concentration distribution is shown in figure $5(\mathrm{c})$.

\section{Figure 5}




\subsubsection{Overall mass transfer coefficient}

The overall mass transfer coefficient $\left(\mathrm{K}_{\mathrm{ov}}\right)$ was calculated from the gas side flux $\left(\mathrm{N}_{\mathrm{CO}_{2}-\mathrm{g}}\right)$ and concentration gradient through the membrane. Equations 29-31 were used to estimate $\mathrm{K}_{\mathrm{ov}}$.

$N_{\mathrm{CO}_{2}-\mathrm{g}}=\frac{Q_{g-\text { in }} C_{\mathrm{CO}_{2}-\text { in }}-Q_{g-o u t} C_{\mathrm{CO}_{2}-\mathrm{out}}}{A}=K_{o v} \Delta C_{g-\mathrm{lm}}$

Where $Q_{g-\text { in }}$ and $Q_{g-o u t}$ are gas side inlet and outlet flow rates $\left(m^{3} \cdot s^{-1}\right)$, respectively, $C_{\mathrm{CO}_{2}-i n}$ and $\mathrm{C}_{\mathrm{CO}_{2} \text {-out }}$ are gas side inlet and outlet concentrations $\left(\mathrm{mol} . \mathrm{m}^{-3}\right)$ of $\mathrm{CO}_{2}$, respectively, while A denotes the active area $\left(\mathrm{m}^{2}\right)$ of membrane. $C_{\mathrm{CO}_{2}-\text { out }}$ was found from the following boundary integral equation.

$C_{\mathrm{CO}_{2}-\text { out }}=\frac{\iint_{r=0}^{r=r_{1}} C_{\mathrm{CO}_{2}-\text { tube }}(r) r d r d \theta}{\iint_{r=0}^{r=r_{1}} r d r d \theta}$

$\Delta C_{g-l m}$ in equation (29) represents logarithmic mean of driving force based on gas phase concentration which can be calculated using equation 31 .

$\Delta C_{g-l m}=\frac{\left(C_{g-\text { in }}-C_{g-\text { in }}^{*}\right)-\left(C_{g-\text { out }}-C_{g-\text { out }}^{*}\right)}{\ln \left(\frac{C_{g-\text { in }}-C_{g-\text { in }}^{*}}{C_{g-\text { out }}-C_{g-\text { out }}^{*}}\right)}$

Where $C_{g-\text { in }}^{*}$ and $C_{g-o u t}^{*}$ in equation 31 represents concentration of the gas phase in equilibrium with corresponding $\mathrm{CO}_{2}$ concentration in the liquid phase $C_{l}^{*}$. Henry's Law constant $\left(C_{g}^{*}=H_{d} C_{l}^{*}\right)$ is used to measure the equilibrium concentration of gas phase. The process was based on recirculation of IL in the shell side of the contactor. This resulted in variation of concentration gradient with time as the IL became more concentrated with $\mathrm{CO}_{2}$. The drop-in concentration gradient directly affects the overall mass transfer coefficient. Figure 6 represents the variation of $\mathrm{K}_{\mathrm{ov}}$ in the first 100 minutes of recirculation. Values of $\mathrm{K}_{\mathrm{ov}}$ are much higher for [emim] [OAc] than for [emim] $\left[\mathrm{EtSO}_{4}\right]$ and [emim] $\left[\mathrm{MeSO}_{4}\right]$. Initially, the values of $\mathrm{K}_{\mathrm{ov}}$ were very high, after they dropped rapidly in the first 20 minutes of recirculation. The drop became gradual and small for further recirculations. After 100 minutes, $K_{o v}$ for [emim][OAc], [emim] $\left[\mathrm{EtSO}_{4}\right]$ and $[\mathrm{emim}]\left[\mathrm{MeSO}_{4}\right]$ was recorded as $\left.2.6 \times 10^{-6}\left(\mathrm{~m} . \mathrm{s}^{-1}\right), 0.14 \times 10^{-6}\left(\mathrm{~m}^{-1}\right)^{-1}\right)$ and $0.065 \times 10^{-6}$ $\left(\mathrm{m} . \mathrm{s}^{-1}\right)$, respectively.

Figure 6

\subsection{Steady-state mode}

\subsubsection{Transient state study}

Steady-state conditions can be achieved by passing both gas and IL from the membrane contactor in a non-closed loop. To achieve steady-state conditions throughout the membrane contactor, it must pass from the transient state during which concentration changes with time, until reaching steady-state conditions. Equation 8, 12 and 17 were used to study the changes in concentration of $\mathrm{CO}_{2}$ with time until reaching steady-state conditions. Figure 7 shows variation in concentration of $\mathrm{CO}_{2}$ at a point inside the tube at the length of $\mathrm{L} / 3$. In the first minute of the absorption, the $\mathrm{CO}_{2}$ concentration increases very fast as the gas mixture is introduced to the tube side of the contactor. A gradual increase can be seen after 1 
minute of the absorption operation. The absorption process does not reach steady-state very quickly as there is a very small increment to $\mathrm{CO}_{2}$ concentration with further passage of the absorption time. The absorption process can be considered steady-state after 2.5-3 minutes as the $\mathrm{CO}_{2}$ concentration becomes uniform at this point inside the tube. After achieving steady-state inside the contactor, the setup can be further studied for effect of different parameters.

\section{Figure 7}

\subsubsection{Solubility and diffusivity study: Effect of temperature}

Unlike other conventional absorbents ILs can be used at high temperatures as their boiling points are close to or even higher than their decomposition temperatures ${ }^{66}$. The maximum temperature level kept for the current analysis was $353.15 \mathrm{~K}$. This value is far lower from the decomposition temperatures of the three ILs $\left([\mathrm{emim}][\mathrm{OAc}]=461 \mathrm{~K}^{67}\right.$, $[\mathrm{emim}]\left[\mathrm{EtSO}_{4}\right]=628 \mathrm{~K}{ }^{68}$ and $\left.[\mathrm{emim}]\left[\mathrm{MeSO}_{4}\right]=635 \mathrm{~K}{ }^{68}\right)$. Temperature affects both solubility and diffusivity of $\mathrm{CO}_{2}$ in ILs. Increase in temperature decreases viscosity which is a favorable feature for enhanced diffusivity. Figure 8 shows the effect of temperature on $\mathrm{CO}_{2}$ diffusivity in the three ILs and gas mixture. Diffusivities were calculated using the correlations mentioned in the preceding sections, equation 5 for gas phase diffusivity and equation 19 for $\mathrm{CO}_{2}$ diffusivity in ILs. Equation 19 developed by Morgan et al. ${ }^{64}$ is based on $\mathrm{CO}_{2}$ diffusivities in imidazolium cation based ILs with different anions. As explained previously, many authors have confirmed this correlation by comparing experimental diffusivities with the diffusivities measured by this correlation

56,65. Temperature dependency of viscosity for the three ILs [emim][OAc], [emim] [EtSO $\left.{ }_{4}\right]$ and [emim] $\left[\mathrm{MeSO}_{4}\right.$ ] have been studied by Nazet et al. ${ }^{59}$; Schmidt et al. ${ }^{60}$ and Costa et al. ${ }^{61}$, respectively. It is evident from the figure 8 that increase in temperature has effectively increased the diffusivity of $\mathrm{CO}_{2}$ in ILs while the change in gas phase is almost negligible.

Figure 8

Solubility of $\mathrm{CO}_{2}$ in ILs is related to Henry's law constant. Indeed, the solubility is negatively affected with increase in temperature ${ }^{55,69}$. The constant calculated using equation 1 was plotted against temperature and reported in figure 9. It was observed that increase in temperature for all three ILs has increased the constant which shows a decrease in solubility. Increasing temperature from $283.15 \mathrm{~K}$ to $353.15 \mathrm{~K}$ increases the constant by 4.2 MPa, 11.1 MPa and 15.1 MPa for the ILs [emim][OAc], [emim][EtSO ${ }_{4}$ ] and [emim] $\left[\mathrm{MeSO}_{4}\right]$, respectively.

\section{Figure 9}

Based on the above findings, temperature has two opposite effects on the absorption of $\mathrm{CO}_{2}$ in room temperature ILs. Increase in temperature significantly reduces the viscosity of ILs, thus enhancing $\mathrm{CO}_{2}$ diffusivity while $\mathrm{CO}_{2}$ solubility in ILs decreases as Henry's law constant increases. To observe the overall effect of temperature on $\mathrm{CO}_{2}$ absorption in ILs, radial concentration of $\mathrm{CO}_{2}$ at tube side was evaluated by defining the same cut line of length $r_{1}$ for all three ILs. A single value of concentration was noted as due to high diffusivity at tube side there was a negligible variation in concentration along the radial length. Table 5 presents values of $\mathrm{CO}_{2}$ concentration (radial) in the tube at different temperatures. Temperature has an evident effect on capture ratio as increasing the temperature has increased the concentration at the outlet. A huge difference in the concentration of $\mathrm{CO}_{2}$ was noted for the three ILs at the same radial 
length. From the results it can be concluded that despite the significant enhancement of $\mathrm{CO}_{2}$ diffusivity with increase in temperature, the overall absorption decreases as the $\mathrm{CO}_{2}$ solubility is negatively affected.

\section{Table 5}

\subsubsection{Concentration drop in partially wetted membrane}

A major challenge in membrane contactor operations is the penetration of the absorbent in the membrane pores which causes wetting of the membrane leading to a significant amount of concentration drop due to increase in mass transfer resistance ${ }^{70,71}$. Simulations of the normalized $\left(C / C_{\max }\right)$ radial concentration drop of $\mathrm{CO}_{2}$ in the $10 \%, 20 \%$ and $50 \%$ wetted portion of the membrane are shown in Figure 10, for [emim] [OAc]. $C$ in the figure represents local $\mathrm{CO}_{2}$ concentration inside the wetted portion of the membrane while $C_{\max }$ is the maximum interfacial $\mathrm{CO}_{2}$ concentration. Concentration drop presented here is only in the wetted portion of the membrane at axial length of $L / 2$. This huge drop of concentration in the wetted portion starts near the gas filled portion of membrane moving towards the shell boundary from where the absorbent is penetrated. A significant drop of $\mathrm{CO}_{2}$ concentration in the wetted portion of the membrane can be observed. When the membrane is $50 \%$ wetted, a concentration drop of $80 \%, 75 \%$ and $72 \%$ can be observed for [emim][OAc]. The same behavior and pattern of concentration drop shown in Figure 10 was observed for [emim] $\left[\mathrm{EtSO}_{4}\right]$ and [emim] $\left[\mathrm{MeSO}_{4}\right]$, respectively (presented in supplementary file). However, at lower wetting ratios the drop in the concentration for [emim] [OAc] was much higher when compared to other two ILs. In case of $10 \%$ wetting a drop of $57 \%$ was observed for [emim] [OAc] while for [emim] [EtSO 4 ] and [emim] $\left[\mathrm{MeSO}_{4}\right]$ it was $34 \%$ and $33 \%$ respectively.

\section{Figure 10}

\subsection{Parametric study}

\subsubsection{Effect of porosity and tortuosity of the hollow fiber membrane}

Porosity $(\varepsilon)$ is a key parameter for membrane absorption process, which directly affects the absorption process. Porosity plays an important role in the development of solute concentration profile, thus influencing the mass transfer process. High porosity can lead to high flux but also increases the chances of membrane wetting, thus a threshold value of porosity must be used ${ }^{9,72}$. Membrane tortuosity $(\tau)$ provides opposite effects than porosity. Increase in tortuosity usually increases the mass transfer resistance of the membrane. Tortuosity for this study was calculated from porosity using equation 32 . The correlation is proposed by Mackie \& Meares ${ }^{73}$, which is known to be very successful for the estimation of tortuosity, verified by the Iversen et al. ${ }^{74}$ for membranes manufactured by phase inversion technique.

$\tau=\frac{(2-\varepsilon)^{2}}{\varepsilon}$

The study in this section is focused on the effect of porosity and tortuosity on the concentration profile of the three ILs. Figures $11 \mathrm{a}$ and $11 \mathrm{~b}$ show the effect of porosity and tortuosity on the gas side dimensionless concentration of $\mathrm{CO}_{2}$ at the outlet of the tube for [emim] $[\mathrm{OAc}]$ and [emim] $\left[\mathrm{EtSO}_{4}\right]$. Both 
physical absorbents [emim] $\left[\mathrm{EtSO}_{4}\right]$ and [emim] $\left[\mathrm{MeSO}_{4}\right]$ (presented in supplementary file) show almost the same effect on concentration profiles for porosity and tortuosity. Initial increase in porosity and decrease in tortuosity affected the $\mathrm{CO}_{2}$ concentration in the tube. Initial Change in porosity ( 0.2 to 0.4 ) and tortuosity ( 16.2 to 6.4 ) decreases the dimensionless $\mathrm{CO}_{2}$ concentration at the outlet of the tube by $0.46,0.42$ and 0.41 for [emim] $[\mathrm{OAc}]$, [emim] $\left[\mathrm{EtSO}_{4}\right]$ and $[\mathrm{emim}]\left[\mathrm{MeSO}_{4}\right]$, respectively. Further change in these parameters has a small effect compared to the initial change. If we consider the IL [emim][OAc], the drop in the concentration was noted to be 0.18 and 0.02 for increasing the porosity value from 0.4 to 0.6 and 0.6 to 0.8 , respectively.

\section{Figure 11}

\subsubsection{Effect of flow rates}

Gas and absorbent flowrates have opposite effects on the $\mathrm{CO}_{2}$ absorption behavior. A smaller gas flow rate and higher absorbent flowrate increases the $\mathrm{CO}_{2}$ removal efficiency ${ }^{21,75}$. The effect of gas and IL flow rates on $\mathrm{CO}_{2}$ absorption was studied for nine different pairs of gas-IL flow rates. A decrease in gas flow rate increases residence time for mass transfer. An increase in IL flow rate provides efficient mass transfer due to increase in treated amount of absorbent and higher concentration gradient. Figure 12 shows dimensionless concentration of $\mathrm{CO}_{2}$ in the tube side against axial length of the contractor. Both

gas/IL flow rates were varied from $20 \mathrm{ml} \cdot \mathrm{min}^{-1}$ to $100 \mathrm{ml} \cdot \mathrm{min}^{-1}$. For all three ILs, 20/100 ml. $\mathrm{min}^{-1}$ pair of

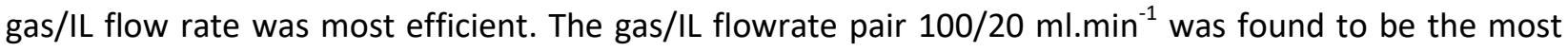
inefficient. It can be noted that gas flow rate has higher effect on the absorption than IL flow rate. While keeping the gas flow rate at $20 \mathrm{ml} \cdot \mathrm{min}^{-1}$ and reducing the IL flow rate to $20 \mathrm{ml} \cdot \mathrm{min}^{-1}$ resulted in a very efficient absorption compared to higher gas flow rates. IL [emim][OAc], due to higher absorption capacity was able to withstand for gas flow rates higher than $100 \mathrm{ml}^{\mathrm{min}}{ }^{-1}$, while other physical absorbents were not able to absorb enough $\mathrm{CO}_{2}$ at higher gas flowrates.

\section{Figure 12}

\section{Conclusions}

A 2-D comprehensive mathematical model for transport of $\mathrm{CO}_{2}$ was developed for a hollow fiber membrane contactor operating in steady-state and pseudo steady-state modes. For pseudo steady-state mode, the model was further linked with a dynamic model of an absorbent tank where ILs used as extractant were recirculated. Developed models were validated with previous reported experimental results for $[\mathrm{emim}][\mathrm{OAc}]$ and $[\mathrm{emim}]\left[\mathrm{EtSO}_{4}\right]$; whereas the $\mathrm{CO}_{2}$ absorption behavior was determined theoretically for the IL [emim] [MeSO $\left.\mathrm{M}_{4}\right]$. Coupled models predict the absorption of $\mathrm{CO}_{2}$ in ILs, which is recirculated from the tank to the shell of the contactor. $\mathrm{CO}_{2}$ solubility in the three ILs were studied in terms of Henry's law constant, which was calculated from experimental PTx data at VLE. Effect of temperature on $\mathrm{CO}_{2}$ solubility and diffusivity were studied, which was further used to see the effect of temperature on $\mathrm{CO}_{2}$ absorption in membrane contactor. Both axial and radial concentration profiles of $\mathrm{CO}_{2}$ were systematically studied. Variations in overall mass transfer coefficient with time were 
investigated. IL [emim] [OAc] was observed to have more $\mathrm{CO}_{2}$ absorption potential and can withstand for a longer time compared to other two ILs. IL [emim][ $\left.\mathrm{MeSO}_{4}\right]$ has shown more efficiency compared to [emim] $\left[\mathrm{EtSO}_{4}\right]$. Overall mass transfer coefficient decreases with high magnitude initially and after some time the decrease become gradual with time. Solubility and diffusivity of $\mathrm{CO}_{2}$ in ILs had strong dependency on temperature. Increase in temperature resulted in higher diffusivity and lower solubility which diminished the $\mathrm{CO}_{2}$ absorption in ILs. Wetted portion of the membrane showed a high magnitude drop in the concentration of $\mathrm{CO}_{2}$. An increase in porosity and decrease in tortuosity reduced the mass transfer resistance in the membrane. Gas/IL flowrate pair of 20/100 ml. $\mathrm{min}^{-1}$ was found very efficient during parametric study. An experimental and modelling work on absorption and stripping of $\mathrm{CO}_{2}$ in HFMCs coupled with other ILs is under study.

\section{References}

1. Atchariyawut, S., Jiraratananon, R. \& Wang, R. Separation of $\mathrm{CO} 2$ from $\mathrm{CH} 4$ by using gas-liquid membrane contacting process. J. Memb. Sci. 304, 163-172 (2007).

2. Atchariyawut, S., Feng, C., Wang, R., Jiraratananon, R. \& Liang, D. T. Effect of membrane structure on mass-transfer in the membrane gas-liquid contacting process using microporous PVDF hollow fibers. J. Memb. Sci. 285, 272-281 (2006).

3. Sreedhar, I., Nahar, T., Venugopal, A. \& Srinivas, B. Carbon capture by absorption - Path covered and ahead. Renew. Sustain. Energy Rev. 76, 1080-1107 (2017).

4. Metz, B. Climate Change 2007: Mitigation. Contribution of Working Group III to the Fourth Assessment Report of the Intergovernmental Panel on Climate Change. Cambridge University Press Cambridge UK and New York NY Retrieved June vol. 26 (2007).

5. Edmonds J. No Title. in Proceedings of the 9th international conference on greenhouse gas control technologies. (2008).

6. MacDowell, N. et al. An overview of CO2 capture technologies. Energy Environ. Sci. 3, 1645 (2010).

7. Freund, P. Making deep reductions in $\mathrm{CO} 2$ emissions from coal-fired power plant using capture and storage of $\mathrm{CO} 2$. Proc Inst Mech Eng Part A J Power Eng 217, 1-8 (2003).

8. Dai, Z., Noble, R. D., Gin, D. L., Zhang, X. \& Deng, L. Combination of ionic liquids with membrane technology: A new approach for CO2separation. J. Memb. Sci. 497, 1-20 (2016).

9. Zhao, S. et al. Status and progress of membrane contactors in post-combustion carbon capture: A state-of-the-art review of new developments. J. Memb. Sci. 511, 180-206 (2016).

10. Rao, A. B. \& Rubin, E. S. A Technical, Economic, and Environmental Assessment of Amine-Based CO 2 Capture Technology for Power Plant Greenhouse Gas Control. Environ. Sci. Technol. 36, 4467-4475 (2002).

11. Li, B., Duan, Y., Luebke, D. \& Morreale, B. Advances in CO2 capture technology: A patent review. Appl. Energy 102, 1439-1447 (2013).

12. Lu, J. G. et al. CO2capture by membrane absorption coupling process: Application of ionic liquids. Appl. Energy 115, 573-581 (2014).

13. Saidi, M. Mathematical modeling of CO2absorption into novel reactive DEAB solution in hollow fiber membrane contactors; kinetic and mass transfer investigation. J. Memb. Sci. 524, 186-196 (2017).

14. Gebremariam, S. K. Modelling a Membrane Contactor for CO2 Capture. (2017).

15. Gabelman, A. \& Hwang, S. Hollow ${ }^{\circledR}$ ber membrane contactors. 159, (1999). 
16. Lu, J. G. et al. CO2capture by membrane absorption coupling process: Experiments and coupling process evaluation. J. Memb. Sci. 431, 9-18 (2013).

17. Lv, Y. et al. Fabrication and characterization of superhydrophobic polypropylene hollow fiber membranes for carbon dioxide absorption. Appl. Energy 90, 167-174 (2012).

18. Eslami, S., Mousavi, S. M., Danesh, S. \& Banazadeh, H. Modeling and simulation of $\mathrm{CO} 2$ removal from power plant flue gas by PG solution in a hollow fiber membrane contactor. Adv. Eng. Softw. 42, 612-620 (2011).

19. Lu, J. G., Zheng, Y. F., Cheng, M. D. \& Wang, L. J. Effects of activators on mass-transfer enhancement in a hollow fiber contactor using activated alkanolamine solutions. J. Memb. Sci. 289, 138-149 (2007).

20. Agrahari, G. K., Verma, N. \& Bhattacharya, P. K. Application of hollow fiber membrane contactor for the removal of carbon dioxide from water under liquid-liquid extraction mode. J. Memb. Sci. 375, 323-333 (2011).

21. Gong, Y., Wang, Z. \& Wang, S. Experiments and simulation of $\mathrm{CO} 2$ removal by mixed amines in a hollow fiber membrane module. Chem. Eng. Process. Process Intensif. 45, 652-660 (2006).

22. Paul, S., Ghoshal, A. K. \& Mandal, B. Theoretical studies on separation of CO2by single and blended aqueous alkanolamine solvents in flat sheet membrane contactor (FSMC). Chem. Eng. J. 144, 352-360 (2008).

23. Wang, R., Li, D. F. \& Liang, D. T. Modeling of CO2 capture by three typical amine solutions in hollow fiber membrane contactors. Chem. Eng. Process. Process Intensif. 43, 849-856 (2004).

24. Saeed, M. \& Deng, L. Post-combustion CO2membrane absorption promoted by mimic enzyme. J. Memb. Sci. 499, 36-46 (2016).

25. Yan, S., He, Q., Zhao, S., Wang, Y. \& Ai, P. Biogas upgrading by CO2 removal with a highly selective natural amino acid salt in gas-liquid membrane contactor. Chem. Eng. Process. Process Intensif. 85, 125-135 (2014).

26. Ramdin, M., De Loos, T. W. \& Vlugt, T. J. H. State-of-the-art of CO \n 2 capture with ionic liquids. Ind. Eng. Chem. Res. 51, 8149-8177 (2012).

27. Blanchard, L. a \& Hancu, D. Green processing using ionic liquids and CO2. Nature 399, 28-29 (1999).

28. Anthony, J. L., Maginn, E. J. \& Brennecke, J. F. Solubilities and Thermodynamic Properties of Gases in the lonic Liquid 1n -Butyl-3-methylimidazolium Hexafluorophosphate. J. Phys. Chem. B 106, 7315-7320 (2002).

29. Rogers, R. D. \& Seddon, K. R. 2003_Seddon_lonic_Liquids_Solvents_of_the_future.

30. Zhang, X. et al. Carbon capture with ionic liquids: overview and progress. Energy Environ. Sci. 5, 6668 (2012).

31. Zhang, J. et al. Supported absorption of CO2 by tetrabutylphosphonium amino acid ionic liquids. Chem. - A Eur. J. 12, 4021-4026 (2006).

32. Shannon, M. S. \& Bara, J. E. Reactive and Reversible lonic Liquids for CO 2 Capture and Acid Gas Removal. Sep. Sci. Technol. 47, 178-188 (2012).

33. Luo, X. \& Wang, C. The development of carbon capture by functionalized ionic liquids. Curr. Opin. Green Sustain. Chem. 3, 33-38 (2017).

34. Mejía, I., Stanley, K., Canales, R. \& Brennecke, J. F. On the high-pressure solubilities of carbon dioxide in several ionic liquids. J. Chem. Eng. Data 58, 2642-2653 (2013).

35. Yokozeki, A., Shiflett Mark, B., Junk Christopher, P., Grieco Liane, M. \& Foo, T. Physical and chemical absorptions of carbon dioxide in room-temperature ionic liquids. J. Phys. Chem. B 112, 16654-16663 (2008).

36. Yim, J. H., Ha, S. J. \& Lim, J. S. Measurement and Correlation of CO2Solubility in 1-Ethyl-3-methylimidazolium ([EMIM]) Cation-Based Ionic Liquids: [EMIM][Ac], [EMIM][CI], and [EMIM][MeSO4]. J. Chem. Eng. Data 63, 508-518 (2018).

37. Shiflett, M. B. \& Yokozeki, A. Phase behavior of carbon dioxide in ionic liquids: [emim][acetate], 
[emim][trifluoroacetate], and [emim][acetate] + [emim][trifluoroacetate] mixtures. J. Chem. Eng. Data 54, 108-114 (2009).

38. Shiflett, M. B. et al. Phase Behavior of $\mathrm{CO}_{2}$ in Room-Temperature lonic Liquid 1-Ethyl-3-Ethylimidazolium Acetate. ChemPhysChem 13, 1806-1817 (2012).

39. Luis, P., Garea, A. \& Irabien, A. Zero solvent emission process for sulfur dioxide recovery using a membrane contactor and ionic liquids. J. Memb. Sci. 330, 80-89 (2009).

40. Albo, J., Luis, P. \& Irabien, A. Carbon Dioxide Capture from Flue Gases Using a Cross-Flow Membrane Contactor and the Ionic Liquid 1-Ethyl-3-methylimidazolium Ethylsulfate. Ind. Eng. Chem. Res. 49, 11045-11051 (2010).

41. Albo, J. \& Irabien, A. Non-dispersive absorption of CO 2 in parallel and cross-flow membrane modules using EMISE. J. Chem. Technol. Biotechnol. 87, 1502-1507 (2012).

42. Gómez-Coma, L., Garea, A. \& Irabien, A. Non-dispersive absorption of CO2in [emim][EtSO4] and [emim][Ac]: Temperature influence. Sep. Purif. Technol. 132, 120-125 (2014).

43. Jie, X., Chau, J., Obuskovic, G. \& Sirkar, K. K. Preliminary studies of CO2 removal from precombustion syngas through pressure swing membrane absorption process with ionic liquid as absorbent. Ind. Eng. Chem. Res. 52, 8783-8799 (2013).

44. Chau, J., Obuskovic, G., Jie, X. \& Sirkar, K. K. Pressure swing membrane absorption process for shifted syngas separation: Modeling vs. experiments for pure ionic liquid. J. Memb. Sci. 453, 61-70 (2014).

45. Finotello, A., Bara, J. E., Camper, D. \& Noble, R. D. Room-temperature ionic liquids: Temperature dependence of gas solubility selectivity. Ind. Eng. Chem. Res. 47, 3453-3459 (2008).

46. Happel, J. Viscous flow relative to arrays of cylinders. AIChE J. 5, 174-177 (1959).

47. Bird, R. B., Stewart, W. E. \& Lightfoot, E. N. Transport Phenomena. Transport Phenomena (2002). doi:10.1016/j.ijhydene.2006.08.059.

48. Fuller, E. N., Schettler, P. D. \& Giddings, J. C. A new method for prediction of binary gas-phase diffusion coefficients. Ind. Eng. Chem. 58, 18-27 (1966).

49. Albo, J., Luis, P. \& Irabien, A. Absorption of coal combustion fl ue gases in ionic liquids using different membrane contactors. Desalin. Water Treat. 27, 54-49 (2011).

50. Dai, Z., Usman, M., Hillestad, M. \& Deng, L. Modelling of a tubular membrane contactor for pre-combustion CO 2 capture using ionic liquids: Influence of the membrane configuration, absorbent properties and operation parameters. Green Energy Environ. 1, 266-275 (2016).

51. Perry, S. et al. Chemical Engineers ' Handbook Seventh. Society vol. 27 (1997).

52. Jalili, A. H. et al. Solubility and diffusion of $\mathrm{CO}$ and $\mathrm{H} 2 \mathrm{~S}$ in the ionic liquid 1-ethyl-3-methylimidazolium ethylsulfate. J. Chem. Thermodyn. 42, 1298-1303 (2010).

53. Soriano, A. N., Doma, B. T. \& Li, M. H. Carbon dioxide solubility in some ionic liquids at moderate pressures. J. Taiwan Inst. Chem. Eng. 40, 387-393 (2009).

54. Wang, G. et al. Low viscosity triethylbutylammonium acetate as a task-specific ionic liquid for reversible $\mathrm{CO} 2$ absorption. J. Chem. Eng. Data 56, 1125-1133 (2011).

55. Lei, Z., Dai, C. \& Chen, B. Gas solubility in ionic liquids. Chem. Rev. 114, 1289-1326 (2014).

56. Zubeir, L. F. et al. Solubility and Diffusivity of $\mathrm{CO}<\mathrm{inf}>2</ \mathrm{inf}>$ in the lonic Liquid 1-Butyl-3-methylimidazolium Tricyanomethanide within a Large Pressure Range (0.01 MPa to 10 MPa). J. Chem. Eng. Data 60, 1544-1562 (2015).

57. Blath, J., Deubler, N., Hirth, T. \& Schiestel, T. Chemisorption of carbon dioxide in imidazolium based ionic liquids with 
carboxylic anions. Chem. Eng. J. 181-182, 152-158 (2012).

58. Sander, R. Compilation of Henry's law constants (version 4.0) for water as solvent. Atmos. Chem. Phys. 15, 4399-4981 (2015).

59. Nazet, A. et al. Densities, Viscosities, and Conductivities of the Imidazolium lonic Liquids [Emim][Ac], [Emim][FAP], [Bmim][BETI], [Bmim][FSI], [Hmim][TFSI], and [Omim][TFSI]. J. Chem. Eng. Data 60, 2400-2411 (2015).

60. Schmidt, H. et al. Experimental study of the density and viscosity of 1-ethyl-3- methylimidazolium ethyl sulfate. J. Chem. Thermodyn. 47, 68-75 (2012).

61. Costa, A. J. L., Esperanca, M. S. S., Marrucho, I. M. \& Rebelo, L. P. N. Densities and Viscosities of 1-Ethyl-3methylimidazolium n -Alkyl Sulfates. J. Chem. Eng. Data 56, 3433-3441 (2011).

62. Gómez, E., González, B., Calvar, N., Tojo, E. \& Domínguez, Á. Physical Properties of Pure 1-Ethyl-3-methylimidazolium Ethylsulfate and Its Binary Mixtures with Ethanol and Water at Several Temperatures. J. Chem. Eng. Data 51, 20962102 (2006).

63. Gómez-Coma, L., Garea, A. \& Irabien, A. Mass Transfer Analysis of $\mathrm{CO}_{2}$ Capture by PVDF Membrane Contactor and lonic Liquid. Chem. Eng. Technol. 40, 678-690 (2017).

64. Morgan, D., Ferguson, L. \& Scovazzo, P. Diffusivities of gases in room-temperature ionic Liquids: Data and correlations obtained using a lag-time technique. Ind. Eng. Chem. Res. 44, 4815-4823 (2005).

65. Moganty, S. S. \& Baltus, R. E. Diffusivity of Carbon Dioxide in Room-Temperature lonic Liquids. Ind. Eng. Chem. Res. 49, 9370-9376 (2010).

66. Rebelo, L. P. N., Lopes, J. N. C., Esperança, J. M. S. S. \& Filipe, E. On the critical temperature, normal boiling point, and vapor pressure of ionic liquids. J. Phys. Chem. B 109, 6040-6043 (2005).

67. Araújo, J. M. M., Pereiro, A. B., Alves, F., Marrucho, I. M. \& Rebelo, L. P. N. Nucleic acid bases in 1-alkyl-3methylimidazolium acetate ionic liquids: A thermophysical and ionic conductivity analysis. J. Chem. Thermodyn. 57, 1-8 (2013).

68. Ficke, L. E. THERMODYNAMIC PROPERTIES OF IMIDAZOLIUM AND PHOSPHONIUM BASED IONIC LIQUID MIXTURES WITH WATER OR CARBON DIOXIDE. (University of Notre Dame, 2010).

69. Okoturo, O. O. \& VanderNoot, T. J. Temperature dependence of viscosity for room temperature ionic liquids. J. Electroanal. Chem. 568, 167-181 (2004).

70. Wang, R., Zhang, H. Y., Feron, P. H. M. \& Liang, D. T. Influence of membrane wetting on CO2 capture in microporous hollow fiber membrane contactors. Sep. Purif. Technol. 46, 33-40 (2005).

71. Mosadegh-Sedghi, S., Rodrigue, D., Brisson, J. \& Iliuta, M. C. Wetting phenomenon in membrane contactors - Causes and prevention. Journal of Membrane Science vol. 452 332-353 (2014).

72. Zhang, W. et al. Effect of porosity on mass transfer of gas absorption in a hollow fiber membrane contactor. J. Memb. Sci. 470, 399-410 (2014).

73. Mackie, J. S. \& Meares, P. The Diffusion of Electrolytes in a Cation-Exchange Resin Membrane. I. Theoretical. Proc. $R$. Soc. A Math. Phys. Eng. Sci. (1955) doi:10.1098/rspa.1955.0234.

74. Iversen, S. B., Bhatia, V. K., Dam-Johansen, K. \& Jonsson, G. Characterization of microporous membranes for use in membrane contactors. J. Memb. Sci. 130, 205-217 (1997).

75. Yan, S. ping et al. Experimental study on the separation of CO2from flue gas using hollow fiber membrane contactors without wetting. Fuel Process. Technol. 88, 501-511 (2007).

76. Quijada-Maldonado, E., Van Der Boogaart, S., Lijbers, J. H., Meindersma, G. W. \& De Haan, A. B. Experimental densities, dynamic viscosities and surface tensions of the ionic liquids series 1-ethyl-3-methylimidazolium acetate and 
dicyanamide and their binary and ternary mixtures with water and ethanol at T = (298.15 to $343.15 \mathrm{~K})$. J. Chem. Thermodyn. 51, 51-58 (2012).

77. Requejo, P. F., González, E. J., Macedo, E. A. \& Domínguez, Á. Effect of the temperature on the physical properties of the pure ionic liquid 1-ethyl-3-methylimidazolium methylsulfate and characterization of its binary mixtures with alcohols. J. Chem. Thermodyn. 74, 193-200 (2014).

78. Almeida, H. F. D., Teles, A. R. R., Lopes-Da-Silva, J. A., Freire, M. G. \& Coutinho, J. A. P. Influence of the anion on the surface tension of 1-ethyl-3- methylimidazolium-based ionic liquids. J. Chem. Thermodyn. 54, 49-54 (2012).

79. Fröba, A. P., Kremer, H. \& Leipertz, A. Density, Refractive Index, Interfacial Tension, and Viscosity of Ionic Liquids

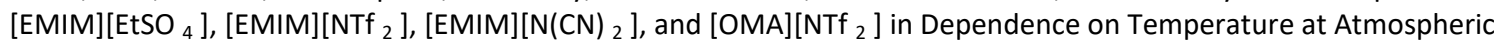
Pressure. J. Phys. Chem. B 112, 12420-12430 (2008).

80. Rilo, E., Domínguez-Pérez, M., Vila, J., Varela, L. M. \& Cabeza, O. Surface tension of four binary systems containing (1ethyl-3-methyl imidazolium alkyl sulphate ionic liquid + water or + ethanol). J. Chem. Thermodyn. 49, 165-171 (2012).

81. Santos, C. S. \& Baldelli, S. Alkyl Chain Interaction at the Surface of Room Temperature lonic Liquids: Systematic Variation of Alkyl Chain Length $\left(\mathrm{R}=\mathrm{C}_{1}-\mathrm{C}_{4}, \mathrm{C}_{8}\right)$ in both Cation and Anion of [RMIM] [R - OSO 3 ] by Sum Frequency G. J. Phys. Chem. B 113, 923-933 (2009). 


\section{Tables:}

Table 1 Specifications of the membrane module and operating conditions

Table 2 Properties of the lonic Liquids at $298 \mathrm{~K}$

Table 3 Boundary conditions for model development

Table 4 Transport parameters and mass transfer kinetics at $298 \mathrm{~K}$

Table 5 Effect of temperature on radial concentration of $\mathrm{CO}_{2}$ in the tube; Steady-state mode; $\boldsymbol{Z}=\boldsymbol{L} / \mathbf{3}$ $Q_{I L}=50 \mathrm{ml} \cdot \mathrm{min}^{-1}, Q_{g}=70 \mathrm{ml} \cdot \mathrm{min}^{-1}, \varphi_{v}=15 \%$, 
Table 2. Specifications of the membrane module and operating conditions.

\begin{tabular}{lll} 
Parameter & Value & unit \\
\hline Membrane material & Polypropylene & - \\
Inside radius of the tube $\left(r_{1}\right)$ & $1.1 \times 10^{-4}$ & $\mathrm{~m}$ \\
Outside radius of the tube $\left(r_{2}\right)$ & $1.5 \times 10^{-4}$ & $\mathrm{~m}$ \\
Membrane thickness $(\delta)$ & $0.4 \times 10^{-4}$ & $\mathrm{~m}$ \\
Length of the contactor $(\mathrm{L})$ & 0.115 & $\mathrm{~m}$ \\
Number of fibers $(\mathrm{n})$ & 2300 & - \\
Membrane pore diameter $\left(\mathrm{d}_{\mathrm{p}}\right)$ & 0.04 & $\mu \mathrm{m}$ \\
Effective inner membrane area $(\mathrm{A})$ & 0.18 & $\mathrm{~m}^{2}$ \\
Porosity $(\boldsymbol{\varepsilon})$ & 40 & $\%$ \\
Packing factor & 0.39 & - \\
Tortuosity $(\boldsymbol{\tau})^{\mathrm{a}}$ & 2.5 & - \\
CO ${ }_{2}$ amount in feed gas $\left(\boldsymbol{\varphi}_{v}\right)$ & 15 & $\mathrm{Vol} \%$ \\
Gas flow rate $\left(\mathrm{Q}_{\mathrm{g}}\right)^{\mathrm{b}}$ & 70 & $\mathrm{ml} \cdot \mathrm{min}^{-1}$ \\
Liquid flow rate $\left(\mathrm{Q}_{1 \mathrm{~L}}\right)^{\mathrm{c}}$ & 50 & $\mathrm{ml}^{\mathrm{c}} \cdot \mathrm{min}^{-1}$ \\
\hline
\end{tabular}

${ }^{\text {a }}$ Assumed as $\frac{(2-\varepsilon)^{2}}{\varepsilon}$

${ }^{b, c}$ Constant, unless mentioned 
Table 2. Properties of the lonic Liquids at $298 \mathrm{~K}$

\begin{tabular}{|c|c|c|c|c|}
\hline Property & Value & Purity & $w\left(\mathrm{H}_{2} \mathrm{O}\right)$ & Reference \\
\hline \multicolumn{5}{|c|}{ Viscosity: $\mu$ (mPa.s); $298 \mathrm{~K}$} \\
\hline \multirow[t]{2}{*}[\mathrm{emim}]{$[\mathrm{OAc}]$} & 141.1 & $>0.95 \mathrm{w} / \mathrm{w}$ & $1.25 \times 10^{-3}$ & 59 \\
\hline & 132.9 & $>0.95 \mathrm{w} / \mathrm{w}$ & $1.30 \times 10^{-3}$ & 76 \\
\hline \multirow{2}{*}[\mathrm{emim}]{$\left[\mathrm{EtSO}_{4}\right]$} & 097.2 & $\geq 0.98 \mathrm{w} / \mathrm{w}$ & $3.00 \times 10^{-4}$ & 60 \\
\hline & 101.4 & - & & 76 \\
\hline$[\mathrm{emim}]\left[\mathrm{MeSO}_{4}\right]$ & 078.8 & $99 \%$ & - & 61 \\
\hline \multicolumn{5}{|c|}{ Density: $\rho$ (g.cm-3); $298 \mathrm{~K}$} \\
\hline \multirow[t]{2}{*}{ [emim] $[\mathrm{OAc}]$} & 1.099 & $>0.95 \mathrm{w} / \mathrm{w}$ & $1.25 \times 10^{-3}$ & 59 \\
\hline & 1.097 & $>0.95 \mathrm{w} / \mathrm{w}$ & $1.30 \times 10^{-3}$ & 76 \\
\hline \multirow[t]{2}{*}{ [emim] $\left[\mathrm{EtSO}_{4}\right]$} & 1.237 & $\geq 0.98 \mathrm{w} / \mathrm{w}$ & $3.00 \times 10^{-4}$ & 60 \\
\hline & 1.240 & - & & 76 \\
\hline \multirow[t]{2}{*}[\mathrm{emim}]{$\left[\mathrm{MeSO}_{4}\right]$} & 1.282 & $>99 \%$ & - & 61 \\
\hline & 1.280 & $>0.99 \mathrm{w} / \mathrm{w}$ & - & 77 \\
\hline \multicolumn{5}{|c|}{ Surface Tension : $\curlyvee(m N . m-1) ; 298 K$} \\
\hline \multirow[t]{2}{*}{ [emim] [OAc] } & 43.00 & $>0.95 \mathrm{w} / \mathrm{w}$ & $1.30 \times 10^{-3}$ & 76 \\
\hline & 47.10 & - & $4.60 \times 10^{-4}$ & 78 \\
\hline \multirow[t]{2}{*}{ [emim] $\left[\mathrm{EtSO}_{4}\right]$} & 47.00 & $>99 \%$ & - & 79 \\
\hline & 47.13 & - & $2 \times 10^{-4}$ & 80 \\
\hline$[\mathrm{emim}]\left[\mathrm{MeSO}_{4}\right]$ & 63.00 & - & - & 81 \\
\hline
\end{tabular}


Table 3 Boundary conditions for model development

\begin{tabular}{|c|c|c|c|}
\hline Boundary & Tube Side & Porous Membrane & Shell Side \\
\hline$z=\mathbf{0}$ & $C_{\mathrm{CO}_{2}-\text { tube }}=C_{0}$ & No Flux & Convective flux \\
\hline \multirow[t]{2}{*}{$z=L$} & Convective flux & No Flux & $C_{\mathrm{CO}_{2}-\text { shell }}=0$ (steady state $)$ \\
\hline & & & $C_{\mathrm{CO}_{2}-\text { tank }}(t+\Delta t)($ pseudo steady state $)$ \\
\hline $\boldsymbol{r}=\mathbf{0}$ & $\frac{\partial C_{\mathrm{CO}_{2}-t u b e}}{\partial r}=0$ & - & - \\
\hline$r=r_{1}$ & $C_{\mathrm{CO}_{2}-\text { tube }}=C_{\mathrm{CO}_{2}-\text { membrane }}$ & $C_{\mathrm{CO}_{2}-\text { membrane }}=C_{\mathrm{CO}_{2}-\text { tube }}$ & - \\
\hline$r=r_{2}$ & - & $C_{\mathrm{CO}_{2}-\text { membrane }}=\frac{C_{\mathrm{CO}_{2}-\text { shell }}}{\dot{\mathrm{m}}}$ & $C_{\mathrm{CO}_{2}-\text { shell }}=\mathrm{m} \quad C_{\mathrm{CO}_{2}-\text { membrane }}$ \\
\hline$r=r_{3}$ & - & - & $\frac{\partial C_{\mathrm{CO}_{2}-\text { shell }}}{\partial r}=0$ \\
\hline
\end{tabular}


Table 4 Transport parameters and mass transfer kinetics at $298 \mathrm{~K}$

\begin{tabular}{|c|c|c|}
\hline Parameter & Value & Reference \\
\hline \multicolumn{3}{|c|}{ Reaction Kinetics: [emim][OAc] } \\
\hline $\mathrm{K}_{\text {eq }}$ & $220.3 \pm 13.4$ & 35,38 \\
\hline$\Delta \hat{\mathrm{H}}\left(\mathrm{KJ} \cdot \mathrm{mol}^{-1}\right)$ & $-30.81 \pm 0.46$ & 35,38 \\
\hline$K_{r}\left(s^{-1}\right)$ & $2.7 \times 10^{-3}$ & 63 \\
\hline $\mathrm{E}\left(\mathrm{KJ} . \mathrm{mol}^{-1}\right)$ & 9.2 & 63 \\
\hline \multicolumn{3}{|c|}{ Henry's law constant: H (MPa), 298K } \\
\hline [emim][OAc] & 1.25 & This work, Equation 10 \\
\hline$[\mathrm{emim}]\left[\mathrm{EtSO}_{4}\right]$ & 11.70 & This work, Equation 10 \\
\hline$[\mathrm{emim}]\left[\mathrm{MeSO}_{4}\right]$ & 5.86 & This work, Equation 10 \\
\hline \multicolumn{3}{|c|}{ Diffusivity of $\mathrm{CO}_{2}$ in ILs: $\mathrm{D}_{\mathrm{CO}_{2}}\left(\mathrm{~cm}^{2} \cdot \mathrm{s}^{-1}\right), 298 \mathrm{~K}$} \\
\hline [emim][OAc] & $2.64 \times 10^{-06}$ & This work, Equation 19 \\
\hline$[\mathrm{emim}]\left[\mathrm{EtSO}_{4}\right]$ & $3.38 \times 10^{-06}$ & This work, Equation 19 \\
\hline$[\mathrm{emim}]\left[\mathrm{MeSO}_{4}\right]$ & $3.88 \times 10^{-06}$ & This work, Equation 19 \\
\hline \multicolumn{3}{|c|}{ Overall mass transfer coefficient: $K_{o v}\left(m \cdot s^{-1}\right), t=0$} \\
\hline [emim][OAc] & $7.61 \times 10^{-05}$ & This work, Equation 29 \\
\hline$[\mathrm{emim}]\left[\mathrm{EtSO}_{4}\right]$ & $1.63 \times 10^{-05}$ & This work, Equation 29 \\
\hline$[\mathrm{emim}]\left[\mathrm{MeSO}_{4}\right]$ & $3.76 \times 10^{-05}$ & This work, Equation 29 \\
\hline
\end{tabular}


Table 5 Effect of temperature on radial concentration of $\mathrm{CO}_{2}$ in the tube; Steady-state mode; $\mathbf{z}=\mathbf{L} / \mathbf{3}$ $Q_{I L}=50 \mathrm{ml} \cdot \mathrm{min}^{-1}, Q_{g}=70 \mathrm{ml} \cdot \mathrm{min}^{-1}, \varphi_{v}=15 \%$,

Temperature (K) Radial concentration, $C_{\mathrm{CO}_{2}-\text { tube }} / \boldsymbol{C}_{\mathbf{0}}$ [emim][OAc] [emim] $\left[\mathrm{EtSO}_{4}\right]$ [emim] $\left[\mathrm{MeSO}_{4}\right]$

291

0.12

0.89

0.31

318

0.18

0.94

0.78

333

0.21

0.97

0.91 


\section{Figures:}

Figure 1 Molecular structures of the cation (a) [emim]; and anions, (b) [OAc], (c) [ $\left[\mathrm{ESO}_{4}\right]$, (d) $\left[\mathrm{MeSO}_{4}\right]$

Figure 2 Schematic representation of setup assumed to be modeled

Figure 3 Schematic diagram of the section used for model development

Figure 4. Validation of simulations with experimental data (a) Simulations of [emim][OAc] with experimental data of $[\mathrm{emim}][\mathrm{OAc}]$, (b) Simulations of $[\mathrm{emim}]\left[\mathrm{EtSO}_{4}\right]$ and $[\mathrm{emim}]\left[\mathrm{MeSO}_{4}\right]$ with experimental data of $[\mathrm{emim}]\left[\mathrm{EtSO}_{4}\right] ; \boldsymbol{Q}_{I L}=\mathbf{5 0 ~} \mathbf{m l} \cdot \mathbf{m i n}^{-1}, \boldsymbol{Q}_{\boldsymbol{g}}=\mathbf{7 0} \mathbf{~ m l} \cdot \mathbf{m i n}^{-1}, \boldsymbol{\varphi}_{v}=\mathbf{1 5} \%$

Figure 5 Dimensionless concentration profile of $\mathrm{CO}_{2}$ in the tube for (a) [emim][OAc], (b) [emim] [EtSO $]$, (c) $[\mathrm{emim}]\left[\mathrm{MeSO}_{4}\right] ; Q_{I L}=50 \mathrm{ml} \cdot \mathrm{min}^{-1}, Q_{g}=\mathbf{7 0} \mathrm{ml} \cdot \mathrm{min}^{-1}, \varphi_{v}=15 \%, T=318 \mathrm{~K}$ at various operating times.

Figure 6. Variation of $\mathrm{K}_{\mathrm{ov}}$ with recirculation time estimated from modelling approach; $Q_{I L}=$ $50 \mathrm{ml}$. $\mathrm{min}^{-1}, Q_{g}=70 \mathrm{ml} . \mathrm{min}^{-1}, \varphi_{v}=15 \%, T=298 \mathrm{~K}$.

Figure 7. Shell side (gas) concentration of $\mathrm{CO}_{2}$ as a function of time estimated from modelling approach; $\mathrm{z}=L / 3, Q_{I L}=50 \mathrm{ml} \cdot \min ^{-1}, Q_{g}=70 \mathrm{ml} \cdot \min ^{-1}, \varphi_{v}=15 \%, T=318 \mathrm{~K}$.

Figure 8 Effect of temperature on $\mathrm{CO}_{2}$ diffusivity in ILs and Gas mixture

Figure 9 Effect of temperature on Henry's law constant of $\mathrm{CO}_{2}$ in ILs

Figure 10. Radial concentration drop of $\mathrm{CO}_{2}$ in wetted portion of membrane for [emim][OAc], estimated from modelling approach; Steady-state mode; $Q_{I L}=\mathbf{5 0 ~ m l . ~} \mathbf{m i n}^{-1}, Q_{g}=\mathbf{7 0 ~ m l . m i n}-\mathbf{m}, \varphi_{v}=$ $15 \%, T=318 \mathrm{~K}$.

Figure 11. Effect of porosity and tortuosity on radial concentration profile of $\mathrm{CO}_{2}$ in the tube for (a) [emim][OAc], (b)[emim][EtSO $\left.{ }_{4}\right]$, estimated from modelling approach. Steady-state mode; $\boldsymbol{Q}_{I L}=$ $50 \mathrm{ml} . \mathrm{min}^{-1}, Q_{g}=70 \mathrm{ml} \cdot \mathrm{min}^{-1}, \varphi_{v}=15 \%, T=318 \mathrm{~K}$.

Figure 12. Effect of gas/IL flow rate on axial concentration profile of $\mathrm{CO}_{2}$ in the tube for (a) [emim] [OAc], (b) $\left[\right.$ emim] $\left[\mathrm{EtSO}_{4}\right]$, (c) $[\mathrm{emim}]\left[\mathrm{MeSO}_{4}\right]$, estimated from modelling approach; Steady-state mode; $\varphi_{\mathrm{v}}=15 \%, \mathrm{~T}=333 \mathrm{~K}$ 


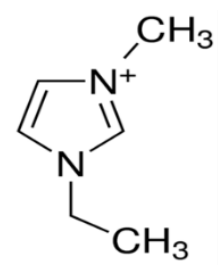

(a)

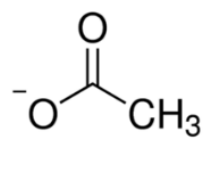

(b)

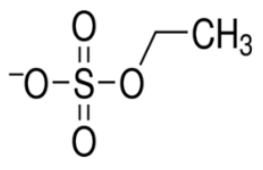

(c)

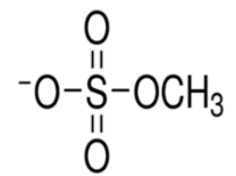

(d)

Figure 13. Molecular structures of the cation (a) [emim]; and anions, (b) [OAc], (c) [EtSO $\left.{ }_{4}\right]$, (d) $\left[\mathrm{MeSO}_{4}\right]$ 


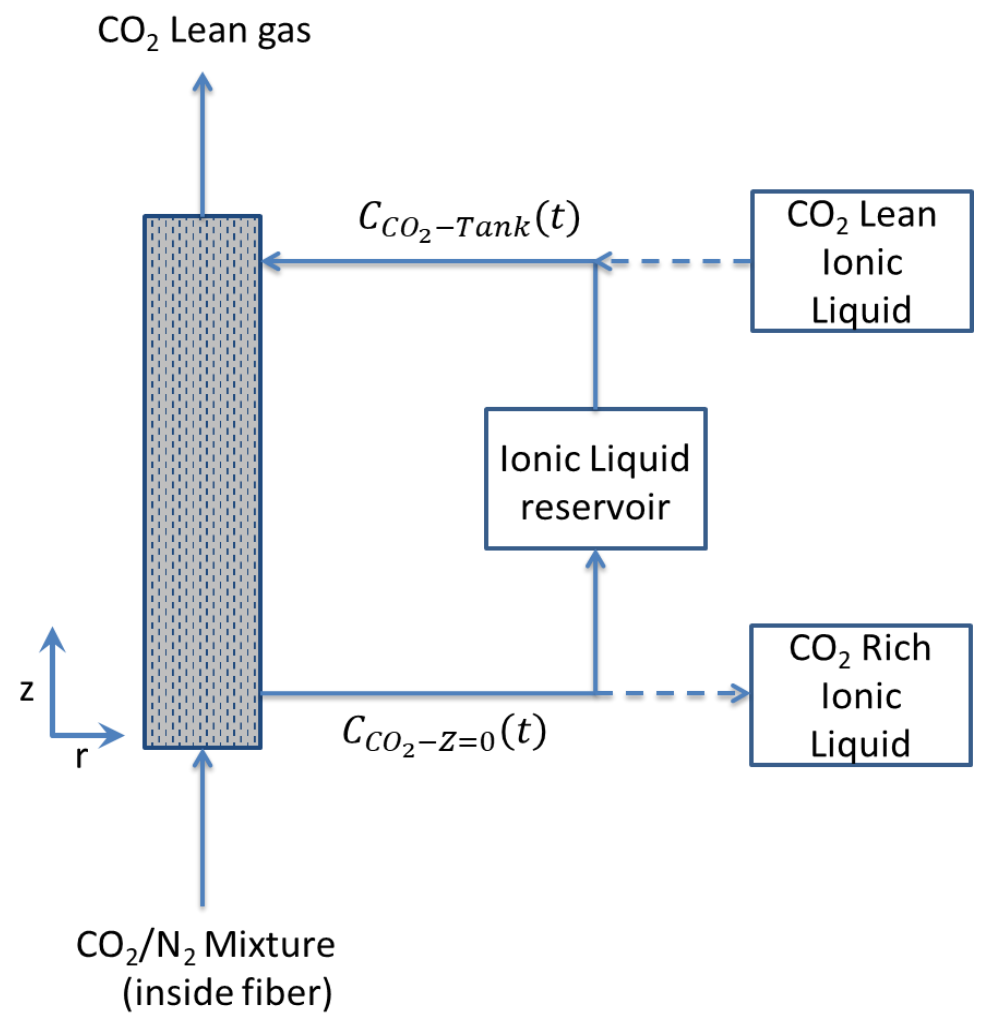

Figure 14. Schematic representation of setup assumed to be modeled 


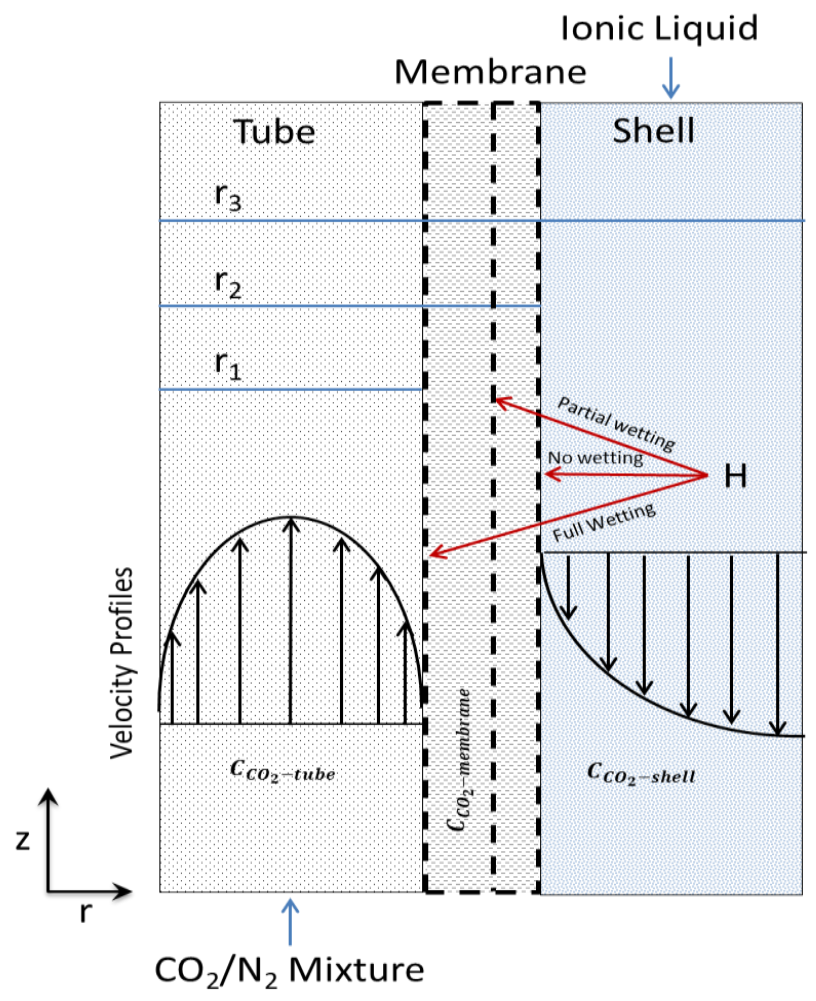

Figure 15. Schematic diagram of the section used for model development 


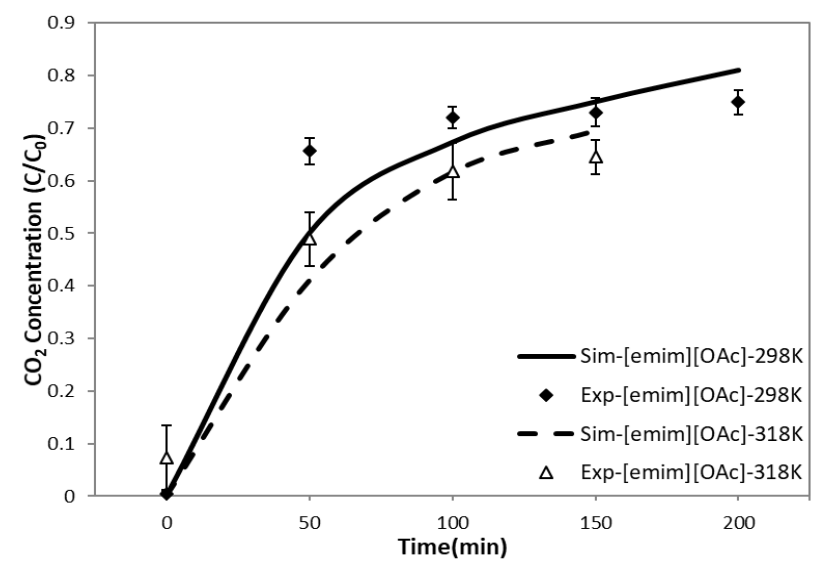

(a)

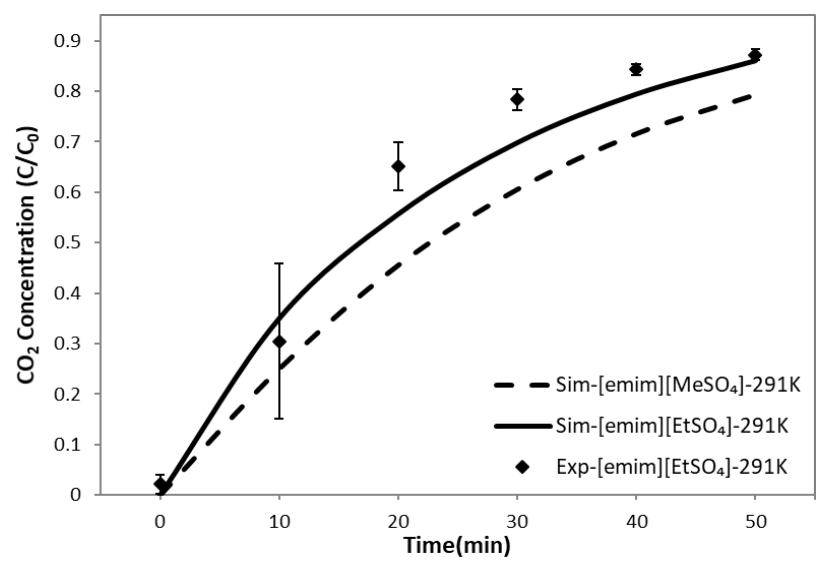

(b)

Figure 16. Validation of simulations with experimental data (a) Simulations of [emim] [OAc] with experimental data of [emim] $[\mathrm{OAc}]$, (b) Simulations of [emim] $\left[\mathrm{EtSO}_{4}\right]$ and [emim] $\left[\mathrm{MeSO}_{4}\right]$ with experimental data of $[\mathrm{emim}]\left[\mathrm{EtSO}_{4}\right] ; \boldsymbol{Q}_{I L}=\mathbf{5 0 ~} \mathbf{m l} \cdot \mathbf{m i n}^{-1}, \boldsymbol{Q}_{\boldsymbol{g}}=\mathbf{7 0 ~} \mathbf{m l} \cdot \mathbf{m i n}^{-1}, \varphi_{v}=15 \%$ 


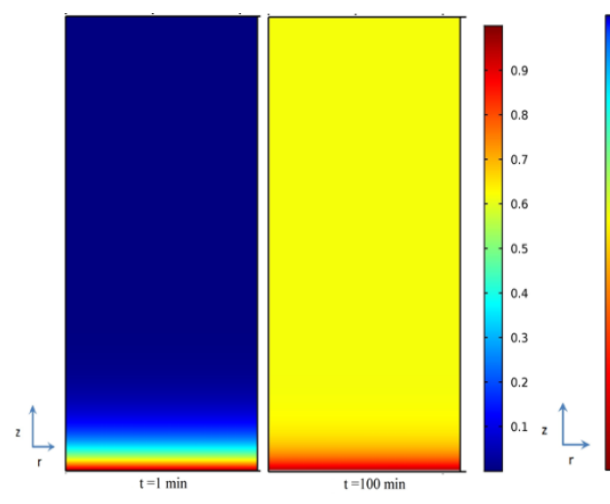

(a)

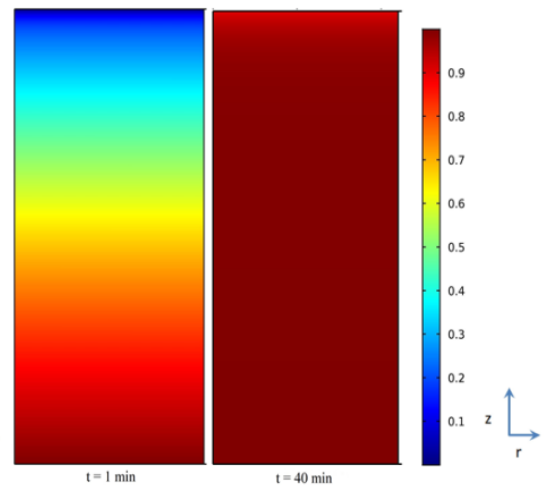

(b)

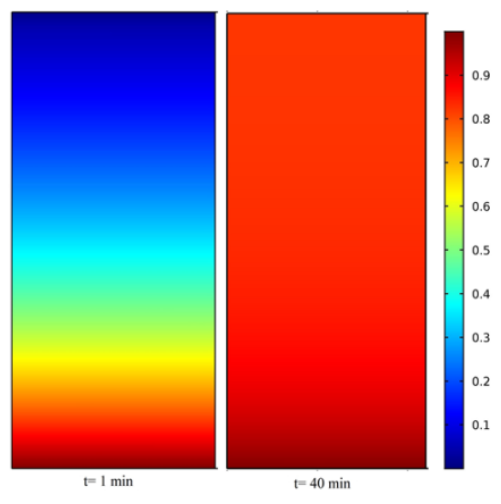

(c)

Figure 17. Dimensionless concentration profile of $\mathrm{CO}_{2}$ in the tube for (a) [emim][OAc], (b)[emim] [EtSO ${ }_{4}$, (c) $[\mathrm{emim}]\left[\mathrm{MeSO}_{4}\right] ; \boldsymbol{Q}_{I L}=\mathbf{5 0} \mathrm{ml} \cdot \mathbf{m i n}^{-1}, \boldsymbol{Q}_{g}=\mathbf{7 0} \mathbf{~ m l} \cdot \mathbf{m i n}^{-1}, \varphi_{v}=\mathbf{1 5} \%, \boldsymbol{T}=\mathbf{3 1 8} \mathrm{K}$ at various operating times. 


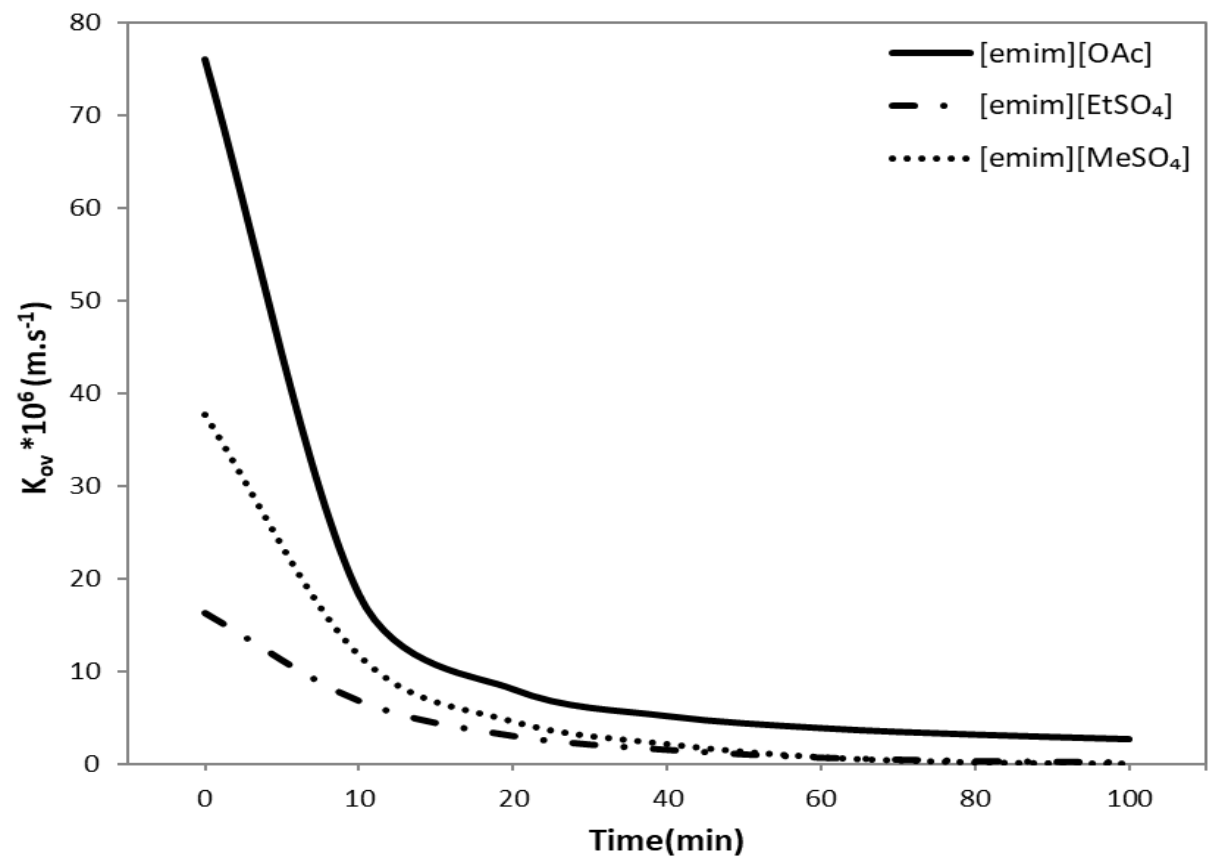

Figure 18. Variation of $\mathrm{K}_{\mathrm{ov}}$ with recirculation time estimated from modelling approach; $\boldsymbol{Q}_{I L}=$ $50 \mathrm{ml} \cdot \mathrm{min}^{-1}, Q_{g}=70 \mathrm{ml} \cdot \mathrm{min}^{-1}, \varphi_{v}=15 \%, T=298 \mathrm{~K}$. 


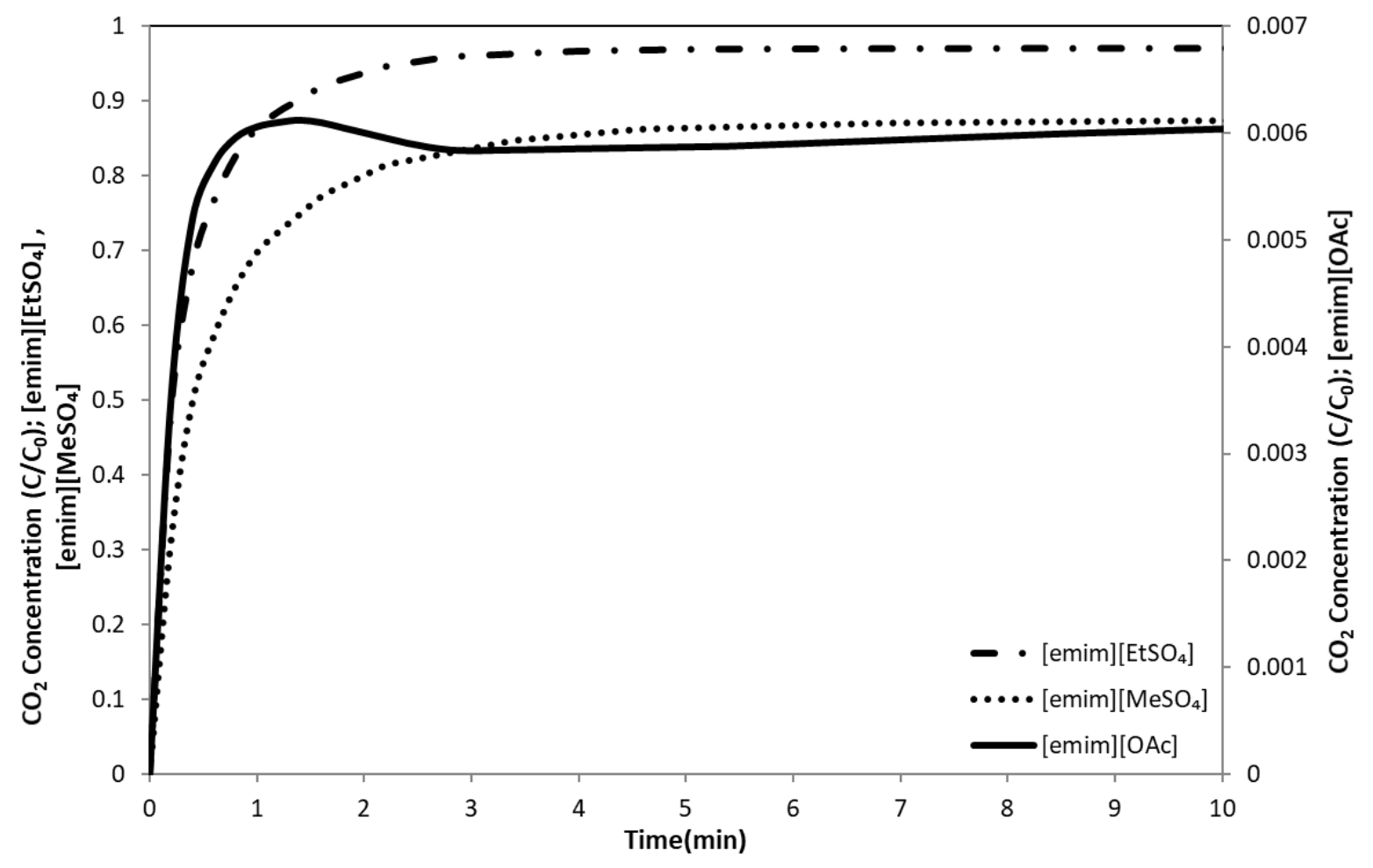

Figure 19. Shell side (gas) concentration of $\mathrm{CO}_{2}$ as a function of time estimated from modelling approach; z $=L / 3, Q_{I L}=50 \mathrm{ml} \cdot \mathrm{min}^{-1}, Q_{g}=70 \mathrm{ml} \cdot \mathrm{min}^{-1}, \varphi_{v}=15 \%, T=318 \mathrm{~K}$. 


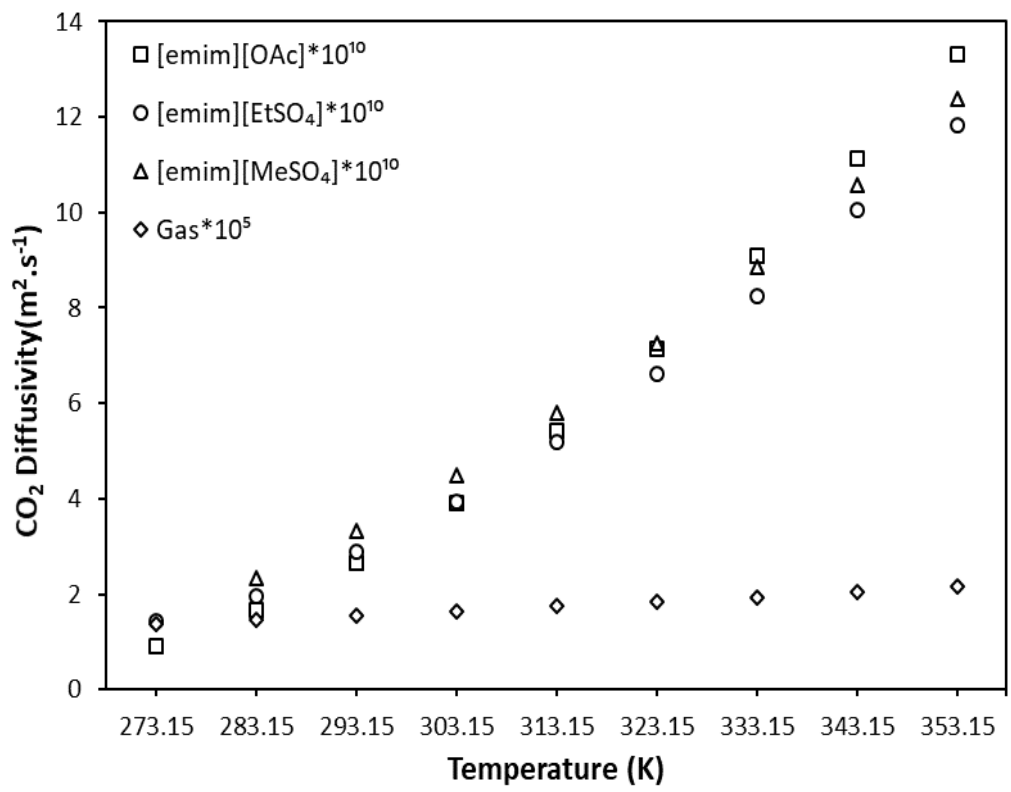

Figure 20. Effect of temperature on $\mathrm{CO}_{2}$ diffusivity in ILs and gas mixture. 


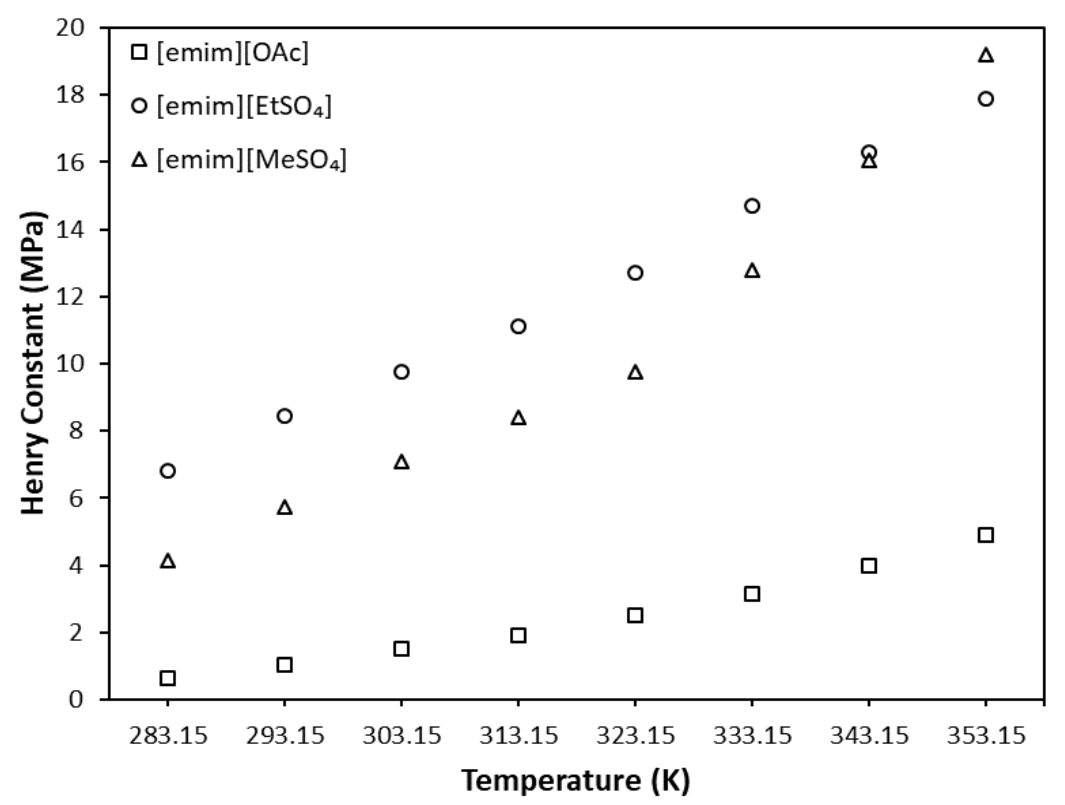

Figure 21. Effect of temperature on Henry's law constant of $\mathrm{CO}_{2}$ in ILs. 


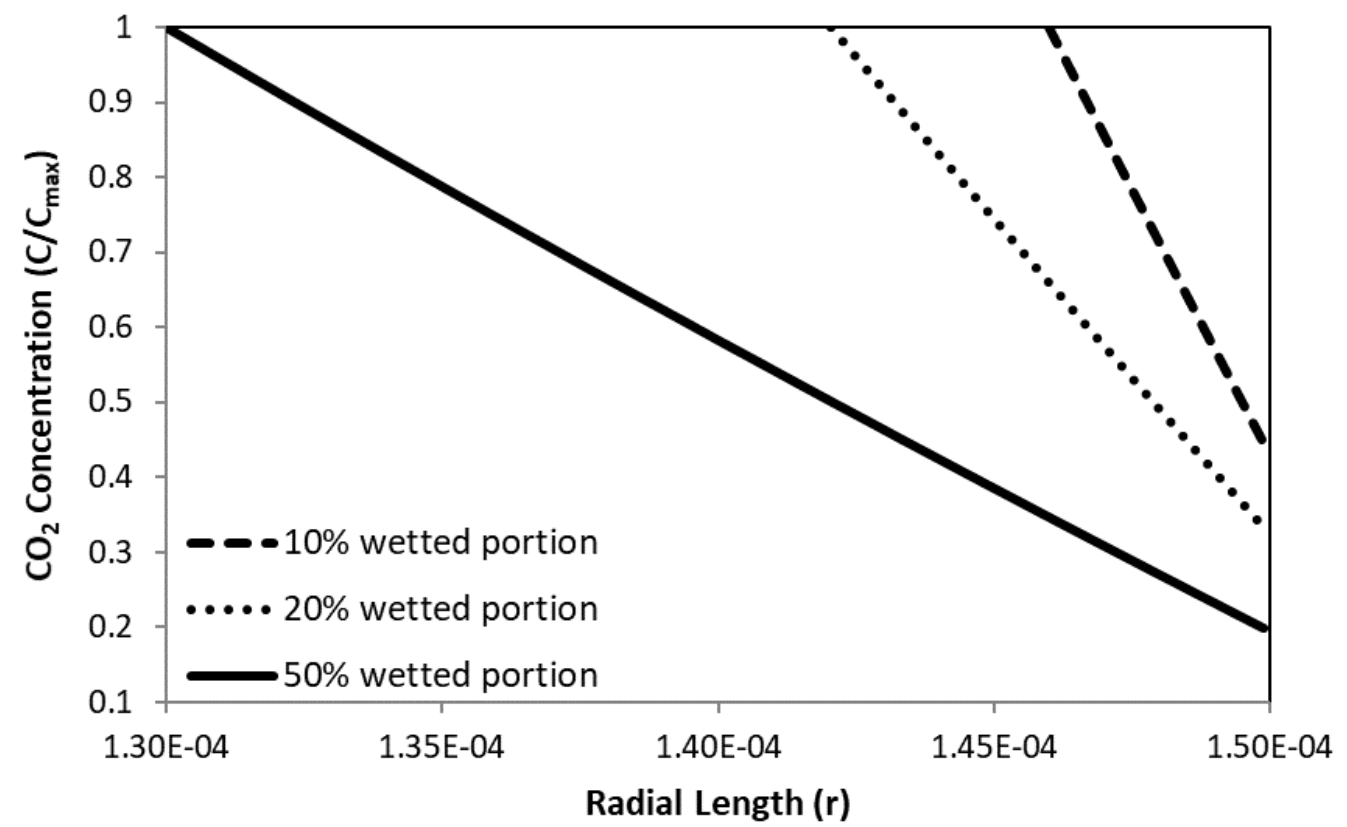

Figure 22. Radial concentration drop of $\mathrm{CO}_{2}$ in wetted portion of membrane for [emim][OAc], estimated from modelling approach; Steady-state mode; $Q_{I L}=50 \mathrm{ml} \cdot \mathrm{min}^{-1}, Q_{g}=70 \mathrm{ml} \cdot \mathrm{min}^{-1}, \varphi_{v}=$ $15 \%, T=318 K$, 


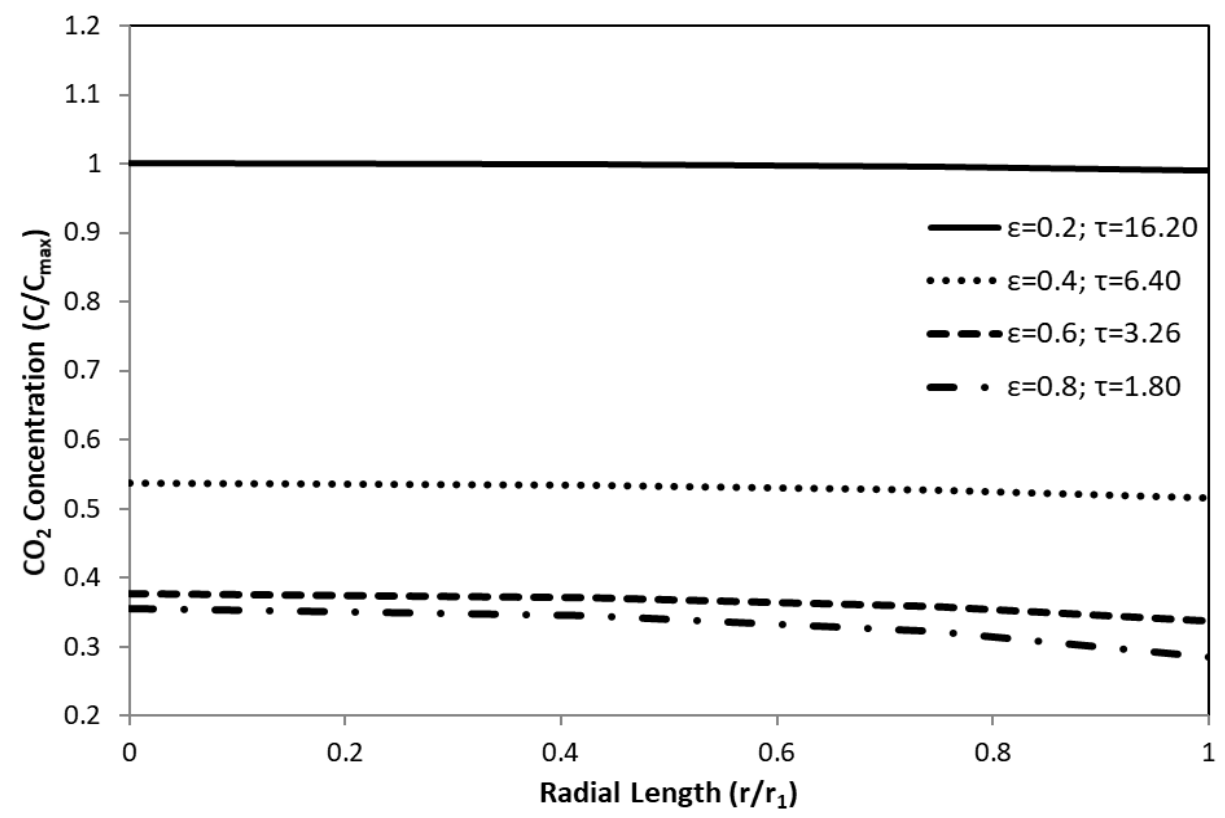

(a)

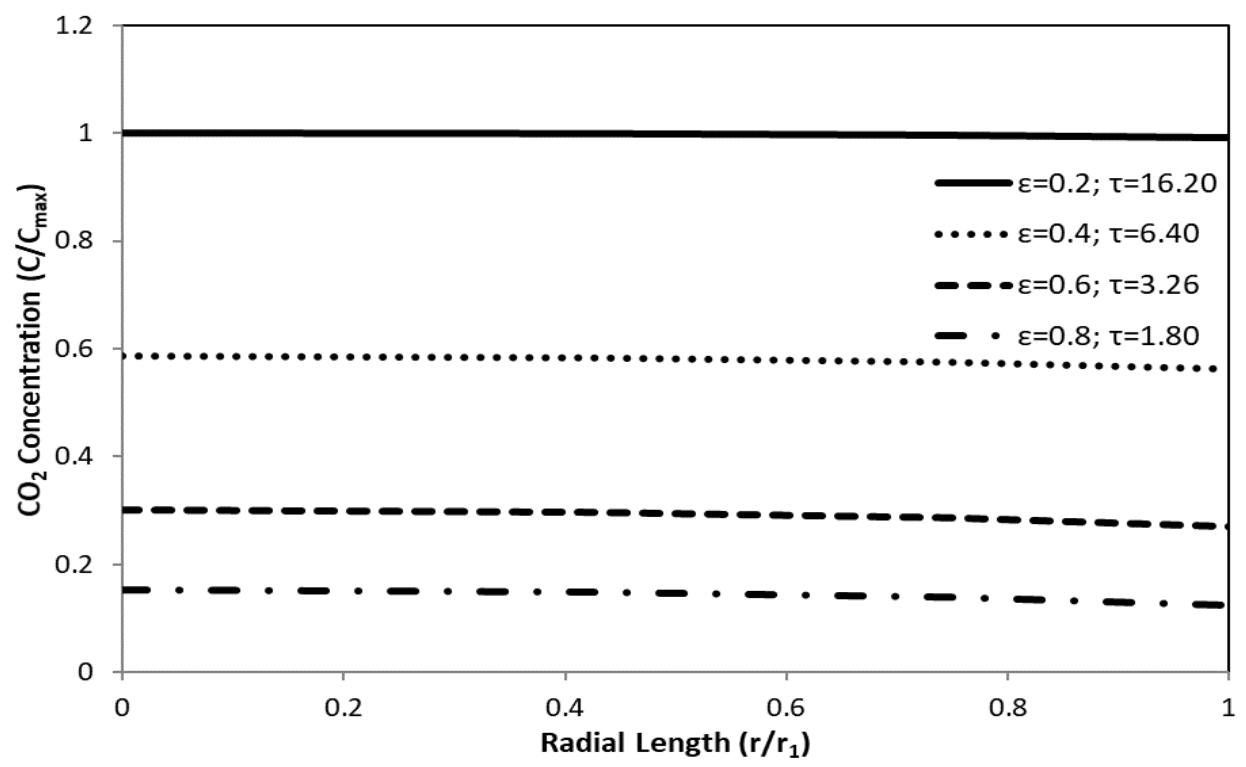

(b)

Figure 23. Effect of porosity and tortuosity on radial concentration profile of $\mathrm{CO}_{2}$ in the tube for (a) [emim][OAc], (b)[emim] [EtSO ${ }_{4}$, estimated from modelling approach. Steady-state mode; $\boldsymbol{Q}_{\boldsymbol{I} \boldsymbol{L}}=$ $50 \mathrm{ml} \cdot \mathrm{min}^{-1}, Q_{g}=70 \mathrm{ml} \cdot \mathrm{min}^{-1}, \varphi_{v}=15 \%, T=318 \mathrm{~K}$. 


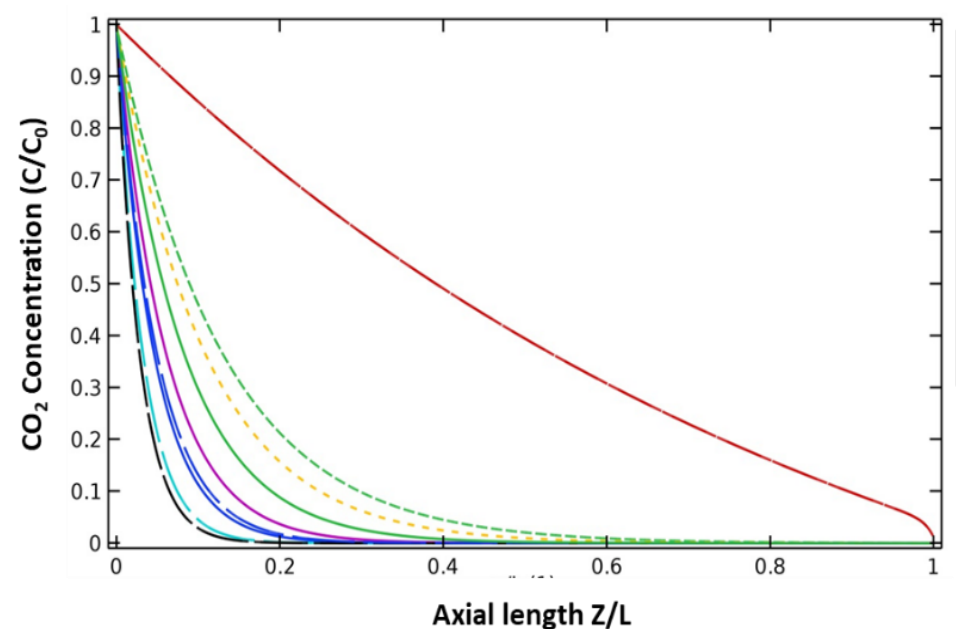

- 1: Q_IL=20 ml.min-1, Q_g=20 ml.min-1 2: Q_IL $=20 \mathrm{ml} \cdot \mathrm{min}-1, Q_{-} \mathrm{g}=60 \mathrm{ml} \cdot \mathrm{min}-1$

- - 3: Q_IL=20 ml.min-1, Q_g =100 ml.min-1

-. - 4: Q_IL=60 ml.min-1, Q_g=20 ml.min-1

— 5: Q_IL=60 ml.min-1, Q_g $=60 \mathrm{ml} \cdot \mathrm{min}-1$

6: Q_IL=60 ml.min-1, Q_g=100 ml.min-1

- - 7: Q_IL=100 ml.min-1, Q_g=20 ml.min-1

-.- 8: Q_L =100 ml.min-1, Q_g=60 ml.min-1

9: Q_IL=100 ml.min-1, Q_g=100 ml.min-1

(a)

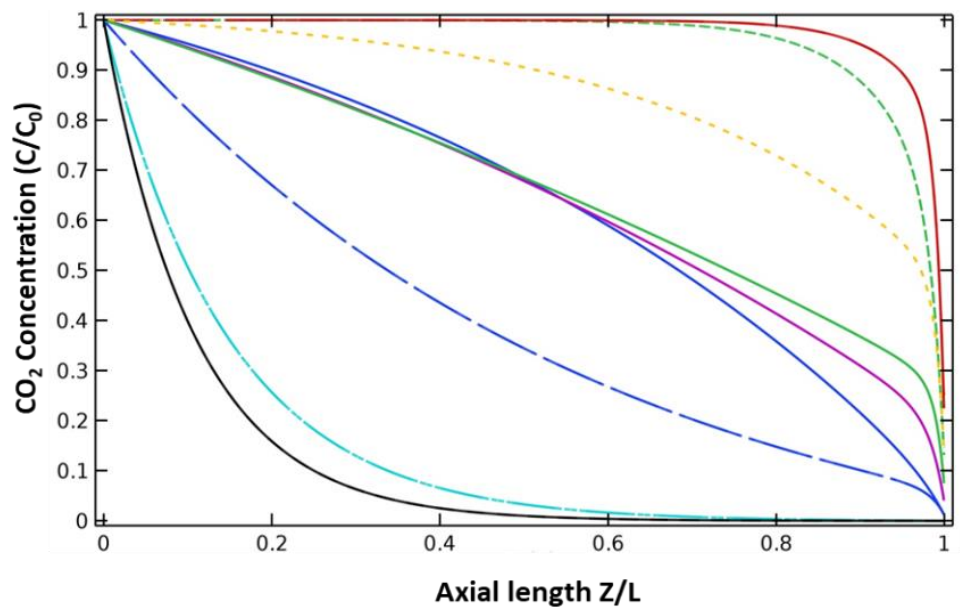

- 1: Q_IL=20 ml.min-1, Q_g = $20 \mathrm{ml} \cdot \mathrm{min}-1$ ….. 2: Q_IL=20 ml.min-1, Q_g $=60 \mathrm{ml} \cdot \mathrm{min}-1$

- - 3: Q_IL=20 ml.min-1, Q_g=100 ml.min-1

-.- 4: Q_IL=60 ml.min-1, Q_g=20 ml.min-1

- 5: Q ILI $=60 \mathrm{ml} \cdot \mathrm{min}-1, Q_{-} \mathrm{g}=60 \mathrm{ml} \cdot \mathrm{min}-1$

6: Q_IL $=60 \mathrm{ml} \cdot \mathrm{min}-1, Q_{-} \mathrm{g}=100 \mathrm{ml} \cdot \mathrm{min}-1$

- - 7: Q_IL=100 ml.min-1, Q_g=20 ml.min-1

.-.- 8: Q_IL=100 ml.min-1, Q_g=60 ml.min-1

— 9: Q_IL=100 ml.min-1, Q_g=100 ml.min-1

(b)

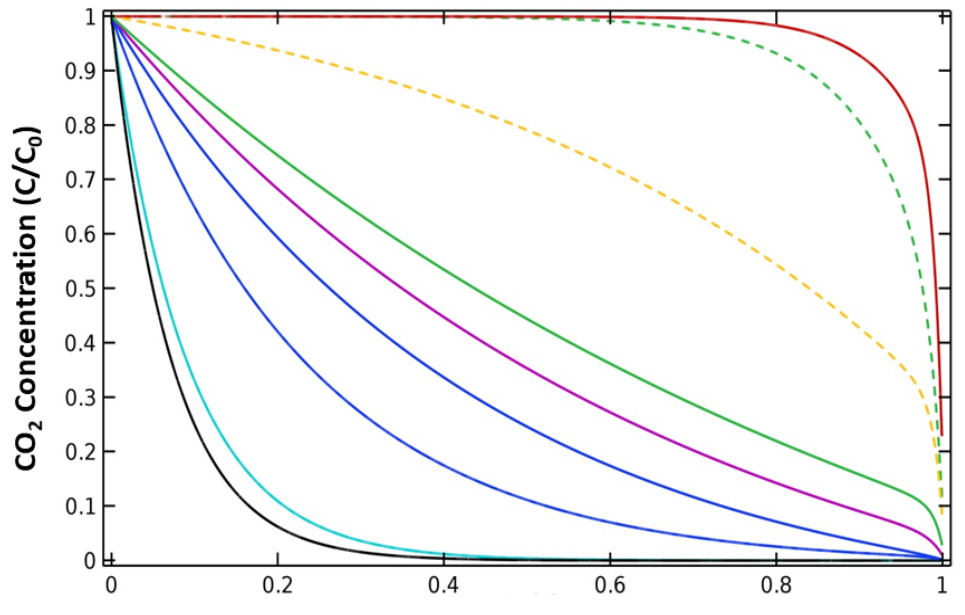

_ 1: Q_IL=20 ml.min-1, Q_g=20 ml.min-1 ...... 2: Q_IL=20 ml.min-1, Q_g=60 ml.min-1 - - 3: Q_IL=20 ml.min-1, Q_g=100 ml.min-1 - _. - 4: Q_IL=60 ml.min-1, Q_g=20 ml.min-1 — 5: Q_ILI $=60 \mathrm{ml} \cdot \mathrm{min}-1, Q_{-} \mathrm{g}=60 \mathrm{ml} \cdot \mathrm{min}-1$ 6: Q_IL=60 ml.min-1, Q_g=100 ml.min-1 - - 7: Q_IL=100 ml.min-1, Q_g=20 ml.min-1 . -. - 8: Q_IL=100 ml.min-1, Q_g=60 ml.min-1 —_ 9: Q_IL=100 ml.min-1, Q_g=100 ml.min-1

Axial length $\mathrm{Z} / \mathrm{L}$

(c)

Figure 24. Effect of gas/IL flow rate on axial concentration profile of $\mathrm{CO}_{2}$ in the tube for (a) [emim] [OAc], (b) $\left[\right.$ emim] $\left[\mathrm{EtSO}_{4}\right]$, (c) $[\mathrm{emim}]\left[\mathrm{MeSO}_{4}\right]$, estimated from modelling approach; Steady-state mode;

$$
\varphi_{\mathrm{v}}=15 \%, \mathbf{T}=333 \mathrm{~K}
$$

